PIOTR TAFIŁOWSKI* - LUBLIN

\title{
BIBLIOTEKI KAPITUL KATEDRALNYCH W GNIEŹNIE I POZNANIU W XV I POCZ. XVI WIEKU
}

\section{Wstęp}

Ośrodki katedralne były w okresie średniowiecza głównymi centrami intelektualnymi. Kapituły (katedralne, ale także kolegiackie) były ośrodkami gromadzącymi najlepiej wykształcony kler, w znacznej mierze posiadaczy uniwersyteckich stopni naukowych, a także notariuszy publicznych. Po odbytych studiach kanonicy i prałaci przywozili ze sobą książki, które stawały się głównym zrębem bibliotek kapitulnych. Ośrodki kapitulne były także centrami szkolnymi, a te nie mogłyby funkcjonować bez podręczników.

Najlepiej rozpoznanymi księgozbiorami polskich kapituł katedralnych są kolekcje: gnieźnieńska, a także krakowska ${ }^{1}$, płocka $^{2}$ i włocławska ${ }^{3}$. Wśród badaczy biblioteki kapituły gnieźnieńskiej wymienić należy na pierwszym miejscu Jadwi-

* Piotr Tafiłowski - dr hab. bibliologii, adiunkt w Zakładzie Informacji Naukowej, Instytut Bibliotekoznawstwa i Informacji Naukowej UMCS, e-mail: p.tafilowski@gmail.com

${ }^{1}$ M. Plezia, Księgozbiór katedry krakowskiej wedle inwentarza z r. 1110, w: Silva Rerum, Kraków 1981; A. Vetulani, Krakowska biblioteka katedralna $w$ świetle swego inwentarza z r. 1100, „Slavia Antiqua”, 4 (1953/54); I. Polkowski, Katalog rękopisów kapitulnych katedry krakowskiej, „Archiwum do dziejów literatury i oświaty w Polsce”, t. 3, Kraków 1884; J. Szujski, Ewangeljarz XI w. kapituly katedralnej krakowskiej, „Sprawozdania Komisji Historri Sztuki”, t. 1, Kraków 1897; K. Antosiewicz, Katalog inkunabutów Biblioteki Kapituly Metropolitalnej w Krakowie, „Analecta Cracoviensia", t. 12, Kraków 1980.

${ }^{2}$ W. Graczyk, J.M. Marszalska, Ksiegi rękopiśmienne i stare druki w zbiorach Biblioteki Wyższego Seminarium Duchownego w Płocku: $z$ dziejów kultury polskich bibliotek kościelnych w dawnych wiekach, Kraków 2010; M. Bersohn, Księgozbiór katedry płockiej, Warszawa 1899; A. Vetulani, Średniowieczne rękopisy płockiej Biblioteki Katedralnej, „Roczniki Biblioteczne”, 7 (1963) z. 3-4; tenże, Biblioteka katedralna płocka, w: Sprawozdania PTPN, Poznań 1964.

${ }^{3}$ Biblioteka Kapituly Włocławskiej, oprac. S. Chodyński, uzup. rozdz. o katalogach i wyd. S. Librowski, Włocławek 1949; B. Iwańska-Cieślik, Biblioteka kapituły katedralnej we Włoclawku, Bydgoszcz 2013. 
gę Rył ${ }^{4}$. Przed II wojną światową jej katalog opracowywali ks. Leon Formano$w_{i c z}{ }^{5}$ oraz Tadeusz Trzciński ${ }^{6}$. Nieco informacji na jej temat można znaleźć także w innych publikacjach ${ }^{7}$. Wiele materiału dostarcza jednak przede wszystkim monumentalna praca księdza Jana Korytkowskiego ${ }^{8}$. Nie zajmowała się natomiast biblioteką w swojej rozprawie doktorskiej Marta Czyżak ${ }^{9}$. Niniejszy tekst, w swej części dotyczącej biblioteki gnieźnieńskiej, jest niejako kontynuacją i uzupełnieniem cytowanych prac.

Kapituła poznańska miała pod tym względem mniej szczęścia. O najdawniejszych rękopisach, które mogły pochodzić z księgozbioru kapitulnego, pisali przed stuleciem Kamil Kantak ${ }^{10}$ i Arkadiusz Lisiecki ${ }^{11}$. W historiografii najnowszej mamy kilka opracowań poświęconych kapitule poznańskiej: Jacka Jaskulskiego ${ }^{12}$, Konrada Lutyńskiego ${ }^{13}$ i Marii Starnawskiej (ta jednak dotyczy okresu wcześniej-

${ }^{4}$ J. Rył, Biblioteka katedralna w Gnieźnie, „Archiwa, Biblioteki i Muzea Kościelne” (dalej: ABMK) 32 (1976), s. 159-248; 33 (1976), s. 237-297; 36 (1978), s. 211-265; Katalog inkunabułów zespołu seminaryjnego Biblioteki Katedralnej w Gnieźnie, ABMK, 25 (1972) s. 115-208; Katalog rękopisów Biblioteki Katedralnej w Gnieźnie, ABMK 45 (1982) s. 5-201; Najstarszy spis ksiązek (1608) Biblioteki Katedralnej w Gnieźnie, „Studia Gnesnensia”, 1 (1975) s. 229-251.

${ }^{5}$ L. Formanowicz, Bibljoteka kapitulna w Gnieźnie, Poznań 1929; tenże, Katalog inkunabułów Biblioteki Kapitulnej w Gnieźnie, z. 1, Poznań 1939; Rekonstrukcja drugiego zeszytu inkunabułów Biblioteki Kapitulnej w Gnieźnie księdza Leona Formanowicza, opr. ks. J. Wojtkowski, ABMK, 18 (1969) s. 81-123; L. Formanowicz, Katalog druków polskich XVI-go wieku Bibljoteki Kapitulnej w Gnieźnie, Poznań 1930.

${ }^{6}$ T. Trzciński, Średniowieczne rękopisy biblioteki kapitulnej w Gnieźnie, „Rocznik Towarzystwa Przyjaciół Nauk Poznańskiego", 35 (1909).

${ }^{7}$ B. Kürbisówna, Udziat Gniezna $w$ dorobku kulturalnym średniowiecznej Polski, w: Dzieje Gniezna, red. J. Topolski, Warszawa 1965, s. 209-217; E. Potkowski, Ksiązka rękopiśmienna w kulturze Polski średniowiecznej, Warszawa 1984, s. 144-153; M. Hornowska, H. Zdzitowiecka-Jasieńska, Zbiory rękopiśmienne w Polsce średniowiecznej, Warszawa 1947, s. 228-231; 248-265.

${ }^{8} \mathrm{~J}$. Korytkowski, Prałaci i kanonicy katedry metropolitalnej gnieźnieńskiej od roku 1000 aż do dni naszych, t. 1-4, Gniezno 1883.

${ }^{9}$ M. Czyżak, Kapituła katedralna w Gnieźnie w świetle Metryki z lat 1408-1448, Poznań 2003.

${ }^{10}$ K. Kantak, Spis książek z XV wieku książnicy seminarium duchownego w Poznaniu, cz. I, Poznań 1921.

${ }^{11}$ A. Lisiecki, Katalog rękopisów biblioteki seminaryjnej w Poznaniu aż do XV w. włącznie, Poznań 1905 (odb. z „Przeglądu Kościelnego”, 7 (1905), 8), s. 1-31.

${ }^{12}$ J. Jaskulski, Kapituła poznańska w pierwszej połowie XV w. Skład osobowy, w: Poznańskie Towarzystwo Przyjaciót Nauk. Sprawozdania 98 za 1980 rok, Wydział Nauk o Sztuce, Poznań 1981; tenże, Problem identyfikacji prebend i ich użytkowników w kapitule katedralnej w Poznaniu w XV w., w: Nihil superfluum esse. Studia z dziejów średniowiecza ofiarowane Profesor Jadwidze Krzyżaniakowej, red. J. Strzelczyk, J. Dobosz, Poznań 2000; tenże, Liczebność kanoników katedralnych $w$ Polsce $w$ drugiej połowie XV wieku, w kontekśsie badań nad kapituła katedralna $w$ Poznaniu, w: Scriptura custos memoriae, red. D. Zydorek, Poznań 2001.

${ }^{13}$ K. Lutyński, Kapituła katedralna w Poznaniu w XVI wieku. Organizacja i majątek, Poznań 2000; tenże, Obsadzanie prebend w kapitule poznańskiej w XVI wieku, „Analecta Cracoviensia”, 27 (1995). 
szego niż ten opisywany w niniejszym artykule) $)^{14}$, a także opublikowane przez Władysława Pawelczaka statuty kapituły poznańskiej ${ }^{15}$. Obszerne studium członkom kapituły poświęcił Paweł Dembiński ${ }^{16}$. Dziejom biblioteki kapituły w XV i XVI wieku nie poświęcono należytej uwagi. Ks. Józef Nowacki planował opisać ją w trzecim tomie swego dzieła o archidiecezji poznańskiej, który dotyczyć miał kapituły metropolitalnej. Bibliotece kapitulnej-katedralnej poświęcony miał być osobny rozdział. Niestety światło dzienne zdążyły ujrzeć jedynie dwa tomy Dziejów Archidiecezji Poznańskiej. Garść wiadomości na temat tejże biblioteki (wykorzystanych także $\mathrm{w}$ tym tekście) znajdujemy $\mathrm{w}$ tomie pierwszym ${ }^{17} \mathrm{i}$ jest to jedyne jak dotąd poświęcone jej, bardzo fragmentaryczne i ze zrozumiałych względów niesystematyczne, opracowanie ${ }^{18}$. Chciałbym, by choć w niewielkim stopniu lukę tę wypełnił niniejszy artykuł.

Oczywiście przygotowany przeze mnie tekst nie rości sobie pretensji do kompletności. Przeciwnie, należy zdawać sobie sprawę, że całościowe, monograficzne opracowanie dziejów bibliotek kapituł poznańskiej i gnieźnieńskiej, choćby tylko dla XV-XVI wieku, wymagałoby poszerzenia kwestionariusza badawczego. Należałoby zatem przebadać przede wszystkim w pełniejszym wymiarze księgi metryczne kapituł oraz przeprowadzić badania proweniencyjne zachowanych woluminów. Być może na marginesie innych spraw jakieś informacje na temat ksiąg znaleźć by można w acta iudiciorum (być może zachowały się jakieś informacje na temat spraw spornych dotyczących niezwróconych ksiąg) czy też acta episcoporum. Być może udałoby się tam odnaleźć zalecenia biskupów względem pomieszczeń bibliotecznych, regulacji wypożyczeń i dostępu do księgozbioru czy też jego uzupełniania, a wreszcie darowizn na rzecz biblioteki. Wpływ osobowości i zainteresowań biskupów na tę kwestię wydaje się być istotny, czego przejawem być może był wzrost zainteresowania produkcją książki drukowanej w kapitule poznańskiej za pontyfikatu Jana Lubrańskiego (1499-1520). Zagadnienie to jednak wymagałoby również odrębnych studiów, zaś wyniki postulowanych kwerend mogłyby być nader skromne. Ponieważ obecnie inne obowiązki nie pozwalają mi podjąc się tej pracy, absorbuje mnie realizacja innych projektów badaw-

${ }^{14} \mathrm{M}$. Starnawska, O sktadzie społecznym kapituły poznańskiej w okresie rozbicia dzielnicowego, „Kwartalnik Historyczny”, 96 (1989) z. 3-4, s. 31-48.

${ }^{15}$ Statuta capituli et ecclesiae cathedralis Posnaniensis ex annis 1298-1763, ed. W. Pawelczak, Poznań 1995.

${ }^{16}$ P. Dembiński, Poznańska kapituła katedralna schyłku wieków średnich : studium prozopograficzne 1428-1500, Poznań 2012; tenże, Udziat prałatów i kanoników w posiedzeniach poznańskiej kapituly katedralnej za pontyfikatu biskupa Uriela z Górki (1479-1498), „Roczniki Historyczne", 66 (2000). s. 171-213.

${ }_{17}$ J. Nowacki, Kościól katedralny w Poznaniu. Studium historyczne, Poznań 1959, s. 563-566 oraz 768-773.

${ }^{18}$ Por. też. Potkowski, Książka rękopiśmienna, s. 142-144; Hornowska, Zdzitowiecka-Jasieńska, Zbiory rękopiśmienne, s. 265-267, 273-290; B. Kürbis, Poznański krąg katedralny. Pismo i ksiązka, w: Dzieje Poznania do roku 1793, t. 1, cz. 1, red. J. Topolski, Warszawa-Poznań 1988, s. 101-106; J. Wiesiołowski, Ksiązka i biblioteki, w: Dzieje Poznania, s. 350-354; tenże, Społeczeństwo a książka w późnośredniowiecznym mieście polskim. Poznań i jego osiedla przedmiejskie wXV i na początku XVI wieku, „Studia Źródłoznawcze”, 23 (1978) s. 65-81. 
czych, a dalszego przebiegu kariery naukowej nie wiążę już z omawianą tu problematyką i najprawdopodobniej nigdy już do niej nie wrócę, sformułowane powyżej postulaty nadal czekają na swego badacza. Zdając sobie sprawę, iż publikacją tą wystawiam się na krytykę części historyków, wyrażam równocześnie przekonanie, że może stać się ona dobrym punktem wyjścia dla przyszłego monografisty bibliotek kapitulnych czy też tworzącego się wokół tych ośrodków środowiska intelektualnego późnego średniowiecza i wczesnej nowożytności.

Kolejnym wreszcie nie omawianym tutaj problemem są kwestie produkcji (przepisywania i iluminowania) ksiąg rękopiśmiennych, w którym to procesie krąg kapitulny odgrywał znaczącą rolę.

Głównym zadaniem mojego tekstu jest, oprócz prezentacji własnych ustaleń, także podsumowanie i usystematyzowanie tych wiadomości, które w pewnej mierze były już wprowadzane do obiegu naukowego, a również przypomnienie samych zapisek źródłowych, których od czasów Bolesława Ulanowskiego nie podawano in extenso ${ }^{19}$. Należy nadmienić, iż wszyscy autorzy piszący dotychczas o bibliotece poznańskiej ograniczali się do wykorzystania większej lub mniejszej części tychże zapisek (ale nigdy wszystkich), zaś najobszerniejsza, trzyczęściowa monograficzna rozprawa Jadwigi Rył poświęcona bibliotece kapituły gnieźnieńskiej wykorzystuje zaledwie niewielką część z cytowanych tutaj notatek. Lektura prac moich poprzedników pozostawia pewien niedosyt, którego również i ten tekst nie będzie w stanie całkowicie zaspokoić, niemniej jestem przekonany, iż w pewnej mierze udało mi się tę lukę wypełnić.

Wybór (ograniczonej) bazy źródłowej wskazuje, że piszę tutaj o stuleciu pomiędzy trzecim dziesiątkiem XV a trzecim dziesiątkiem XVI wieku. By rzucić nieco światła na wcześniejsze dzieje księgozbioru, należałoby, jak już wspomniałem, rozszerzyć zakres poszukiwań, nie mając przy tym gwarancji odniesienia sukcesu. Choć bez wątpienia kapituły gromadziły księgi znacznie wcześniej niż choćby przełom XIV i XV wieku, to jednak dawniejsze dzieje tych księgozbiorów są dziś trudno uchwytne źródłowo. Dlatego też nie podjąłem się badania tychże wcześniejszych dziejów, skupiając się jedynie na przyrastaniu zbiorów bibliotecznych i wypożyczeniach w ciągu XV i początku XVI w.

Co ciekawe, w aktach kapituł, publikowanych przez Bolesława Ulanowskiego, najwięcej zapisek odnoszących się do książek i księgozbiorów pochodzi właśnie z ośrodków gnieźnieńskiego i poznańskiego, jedynie po kilka zaś z włocławskiego (4), krakowskiego (4), płockiego (7) i pułtuskiego (2). Już samo w sobie zjawisko to zasługuje na odrębne rozważenie i zbadanie, czy taki jest rzeczywisty wydźwięk źródeł, czy też różnice te wynikają z metody pracy badacza, który wydając dokumenty czterech ostatnich kapituł zwracał szczególniejszą uwagę na innego rodzaju zagadnienia. W tym miejscu jednak ograniczę się znów tylko do postawienia postulatu badawczego, nie podejmując się jego realizacji.

${ }^{19}$ Acta capitulorum nec non iudiciorum ecclesiasticorum selecta. Vol. I. Acta capitulorum Gneznensis, Poznaniensis et Vladislaviensis (1408-1530), ed. B. Ulanowski, Kraków 1894 (dalej cyt. jako Ulanowski 1894). 


\section{Gniezno}

Początek biblioteki gnieźnieńskiej sięga XI w. Jej zasób kształtowany był w głównej mierze z darów „uczonych kanoników i prałatów, których w Gnieźnie nie brakowało, ich księgozbiory decydowały o charakterze zbioru. Jej księgi miały charakter użytkowy służąc do lektury i nauki kanonikom i oświeconemu klerowi całego kręgu katedralnego Gniezna, a także były wypożyczane do okolicznych kościołów i klasztorów"20. Drogocenne księgi liturgiczne, bogato iluminowane, w złoconych oprawach, a czasem nawet pisane złotem, pochodziły z darów arcybiskupów, ewentualnie innych wyjątkowo zamożnych dobroczyńców (książąt). Sama kapituła jako instytucja niezwykle rzadko dokonywała zakupów książek. Często natomiast spotykamy się z zapiskami regulującymi zasady korzystania z księgozbioru oraz dającymi świadectwo troski o jego stan.

Jak ocenił ks. Jan Korytkowski ,na początku w. XVI biblioteka kapitulna była znaczną i doborową, jak widać z rozmaitych zapisów w aktach kapitulnych od tego czasu, według których prałaci i kanonicy pożyczali dla własnej nauki (ad studendum) księgi rozmaitej treści i takowe po niejakim czasie na inne zamieniali. Widać stąd, że członkowie kapituły, doktorzy i profesorowie, z biblioteki jej pilnie korzystali" 21 .

Rozważania poświęcone bibliotece kapituły gnieźnieńskiej rozpocznę od zagadnienia pomieszczeń bibliotecznych ${ }^{22}$. Aż do drugiej połowy XV w., z powodu braku odpowiedniego miejsca, książki przechowywano w skarbcu kapitulnym oraz na zamku arcybiskupim w Uniejowie. W tym czasie przekonano się, że zarówno w jednym, jak i w drugim miejscu księgi z powodu wilgoci oraz braku przewietrzania butwiały i psuły się, tak że nikt nie miał z nich najmniejszego pożytku. Dlatego też 27 października 1463 r. postanowiono urządzić bibliotekę w dotychczasowym audytorium, czyli lectorium, w którym doktorzy kanonicy uczyli teologii i prawa kanonicznego. Pomieszczenie to położone było nad zakrystią katedralną. Tam też miano umieścić wszystkie książki przechowywane dotychczas zarówno w skarbcu, jak i w zamku. Odpowiedni zapis w aktach kapitulnych brzmi: „Dni habito tractatu de libris hic in thezauro et in Unyeow iacentibus, quomodo propter non revolucionem ipsorum putrescunt et destruuntur, nec alique utilitas hominibus sequitur ex eis, decreverunt fieri librariam in antiquo lectorio supra sacristiam"23.

Jak pisał Jacek Wiesiołowski ,biblioteka kapituły była częściowo przechowywana w skarbcu, częściowo w zakrystii katedry, natomiast podstawowy zasób ksiąg znajdował się w bibliotece, której pomieszczenie powstałe za czasów pry-

${ }^{20}$ J. Wiesiołowski, Średniowieczne biblioteki wielkopolskie, w: Średniowieczna książka rękopiśmienna jako dzieło sztuki, Gniezno 1993, s. 14-15.

${ }^{21}$ J. Korytkowski, Prałaci i kanonicy katedry metropolitalnej gnieźnieńskiej od roku 1000 aż do dni naszych, t. III, Gniezno 1883 (dalej: Korytkowski. Cyfry rzymskie oznaczają kolejne tomy dzieła), s. 504. Biblioteka i jej księgozbiór omawiane są na kolejnych kilkunastu stronach.

${ }^{22}$ Zob. M. Przywecka-Samecka, Z dziejów najstarszych pomieszczeń bibliotecznych w Polsce. Biblioteka Kapitulna w Gnieźnie, „Zeszyty Naukowe Uniwersytetu Wrocławskiego”, Seria A. Bibliotekoznawstwo, 38 (1962) s. 5-27.

${ }^{23}$ Ulanowski 1894, nr 1942. 
masa Trąby przestało wystarczać w poł. XV w." W świetle zapisów akt kapitulnych stwierdzenie to nie znajduje potwierdzenia, nie wskazują one bowiem na to, że przed rokiem 1463 istniało jakiekolwiek oddzielne pomieszczenie spełniające funkcje biblioteczne. Wręcz przeciwnie, jeśli będziemy opierać się tylko na nich dojdziemy do wniosku, że aż do 1467 r. wydzielonej izby bibliotecznej przy katedrze gnieźnieńskiej nie było.

Albowiem z niewiadomych powodów plan ten pozostał przez cztery lata niezrealizowany. Dopiero 25 czerwca 1467 r. ponowiono postanowienie, a jego realizację powierzono kanonikowi i doktorowi medycyny Wojciechowi z Opatowa. Miał on niezwłocznie urządzić bibliotekę we wspomnianym miejscu. Wojciech z Opatowa został „kierownikiem inwestycji” i był za nią osobiście odpowiedzialny. Miał on także sam finansować przedsięwzięcie, wszystkie koszty natomiast miały mu zostać następnie zwrócone ze skarbca kapituły, na co jej członkowie zgodzili się jednogłośnie. Niestety dzieła tego „,dokonać śmierć mu nie pozwoliła"24. Odnośny zapisek brzmi: „Dni... de preparatione librarie et consumacione eiusdem conferentes et tractantes, de qua etiam fuit mencio in capitulo generali ultimo celebrato iuxtaque eiusdem capituli decretum commiserunt vener. viro dno Alberto de Opathowia, in medicinis doctori, eandem librariam dare facere sive procurare ipsorum sumptibus et impensis in ecclesia Gnezn. superius sacristiam, quem dnum doctorem prefati dni racione huiusmodi impensarum promiserunt reddere indampnem unanimi voto"25.

Użyte tutaj określenia (preparatione librarie et consumacione, facere sive procurare) zdają się raczej wskazywać, że chodziło o przygotowanie pierwszego założenia bibliotecznego, nie zaś o urządzenie nowej siedziby i przeniesienie do niej księgozbioru ze starego pomieszczenia (podobnie uważał J. Korytkowski, który nie znał wcześniejszych pomieszczeń bibliotecznych w katedrze gnieźnieńskiej). Nie ma tutaj wzmianki o starej, dotychczasowej siedzibie biblioteki. Nie zamierzam tutaj jednak jednoznacznie rozstrzygać tego zagadnienia.

W aktach kapitulnych nie ma wzmianki, w jakim czasie przeniesiono całą bibliotekę kapitulną nad zakrystię. Wiadomo jedynie, że już pod koniec XV wieku była właśnie tam przechowywana, a nawet została już skatalogowana.

Po przeniesieniu biblioteki do pomieszczenia lektorium dla potrzeb wykładów teologicznych i prawa kanonicznego kapituła przeznaczyła inne pomieszczenie, które jednak, jak się okazało, nie było zbyt dogodne do celów dydaktycznych. 17 grudnia $1491 \mathrm{r}$. Leonard Walknowski, kanonik i doktor teologii, domagał się, aby wykłady odbywały się według starodawnego zwyczaju w izbie, w której umieszczono bibliotekę. Kapituła, uznając z jednej strony słuszność żądania, z drugiej zaś lękając się, aby książki nie uległy rozproszeniu i zagubieniu z powodu przebywania w bibliotece uczniów i posługaczy, nakazała sprawdzić dawne katalogi i skontrolować liczbę skatalogowanych ksiąg, wyznaczywszy do tego kanoników Adriana Żernickiego i Floriana Krosnowskiego. Zapisano wówczas

${ }^{24}$ Korytkowski III, s. 160. Jak podaje tu ks. Korytkowski Wojciech z Opatowa „w r. 1461 przewiózł z zamku uniejowskiego do Gniezna ramię św. Wojciecha oprawione w srebro oraz librum racionalem. Co by to z księga była: rytuał diecezjalny czy też ceremoniał biskupi, nie wiadomo”.

${ }^{25}$ Ulanowski 1894, nr 1999. 
w aktach kapitulnych: „Rdus dnus Leonardus Walconovius, sacre Theol. Dr., petit a Rndis dnis, ut sibi vigore Capituli decerneretur potestas legendi lectiones, ad quas tenetur, in lectorio communi Ecclesie Metrop. pro antiqua consuetudine. Et Rndi dni petitioni huic annuentes, primum, Ne aliquid ex libris Bibliothecae deperdatur, denuo regestra librorum verificanda decreverunt, pro quo officio expediendo deputaverunt Rndos dnos Adrianum Zerniczki et Florianum Krosnowski"26.

O rozwiązaniu tego problemu, czy wykłady prowadzono odtąd w sali bibliotecznej, nie wiemy.

Aż do połowy XVI wieku arcybiskupie Gniezno nie miało własnego zamku obronnego. Projekty jego wybudowania wysuwał w okresie swego pontyfikatu prymas Jan Łaski (1510-1531), jednakże nie zostały one zrealizowane ${ }^{27}$. Dlatego też przez cały interesujący mnie okres wszystkie kosztowności skarbca gnieźnieńskiego, w tym także księgi, wożono w razie zagrożenia do umocnionej rezydencji w Uniejowie. Tak się sprawa miała w roku 1455, po rozpoczęciu wojny zwanej później trzynastoletnią, kiedy to kantor poznański, kanonik i oficjał gnieźnieński Piotr Pniewski ${ }^{28}$ wyruszający do arcybiskupa do Łęczycy, miał też przy okazji zabrać ze sobą drogocenne księgi w srebrnych i pozłacanych oprawach, by zdeponować je w skarbcu zamku uniejowskiego. Zapisek kapitulny z 27 stycznia 1455 wyszczególnia:

„Item missale magnum rubeo examento circumductum cum argenteis clausuris et pukle deauratis

Item liber biblie datus per Vyschotam prepositum Poznan. ${ }^{29}$ cum clausuris et pucle argenteis deauratis

Item missale in flaveo examento cum clausuris et pukle argenteis deauratis

Item missale magnum cum quatuor clausuris de argento et pukle deauratis, in quorum medio aquila desculpta

Item liber Ewangeliarum Greca scriptura aurea circumferencialiter argento deaurato reparato et in una parte Passio Dni cum ymaginibus s. Marie et s. Iohannis a lateribus et in alia parte crux deaurata

Item alius parvus liber de Graca scriptura incausto scriptus et unus asser argento deaurato in toto circumductus, in cuius medio ymago dni Ihesu Christi desculpta ad iudicandum in die iudicii disposita et Ewangeliste de cornibus facti

Item libellus parvus de Greca scriptura cum ymaginibus Ewangelistarum, videlicet Novum Testamentum cum crucibus tribus et circa illa infixis ad modum clavorum parvorum de argento deaurato" ${ }^{30}$.

${ }^{26}$ Powyższe na podstawie: Korytkowski I, s. 502-505.

${ }^{27}$ P. Tafiłowski, Jan Laski (1456-1531), kanclerz koronny i prymas Polski, Warszawa 2007, s. 388-389.

${ }^{28}$ Kanonik, prepozyt gnieźnieński 1455-1456, oficjał generalny gnieźnieński 1455-1457, 1464, 1474-1480, administrator sede vacante po śmierci Jana Odrowąża (1464), prepozyt włocławski, kantor poznański. A. Gąsiorowski, I. Skierska, Średniowieczni oficjałowie gnieźnieńscy, „Roczniki Historyczne”, 61 (1995) s. 80-81; Czyżak, Kapituła katedralna w Gnieźnie, s. 386-387.

${ }^{29}$ Wyszota z Górki. Czyżak, Kapituła katedralna w Gnieźnie, s. 406-407.

${ }^{30}$ Ulanowski 1894, nr 1840. 
Według J. Wiesiołowskiego, ponieważ „trzy księgi były de greca scriptura, wśród nich ewangeliarz gnieźnieński”, pozwala to „na określenie ich jako ksiąg zapewne z XI wieku" ${ }^{\prime 3}$.

Wspaniałe mszały, graduały i antyfonarze zakupione za wielkie sumy pieniężne, najczęściej przez arcybiskupów, były jak widać nie tylko przedmiotem chluby oraz lokatą kapitału. Stanowiły także niemały kłopot. Pomimo, iż nie nadawały się one do zwyczajnego użycia (treść ich z czasem ulegała dezaktualizacji), jednak dla swej niezwykłej wartości materialnej przechowywane były w zasobie skarbcowym. Należało ich jednak strzec nie tylko przed zagrożeniami zewnętrznymi, lecz także wewnętrznymi. Okazało się bowiem, że przed 1605 rokiem księgi te zostały w wandalski sposób uszkodzone przez kapłana, któremu kapituła powierzyła nad nimi pieczę. Czynu tego dopuścił się wikariusz katedralny Wojciech z Rawy, który powycinał z ksiąg miniatury i inicjały, za co został w 1605 roku ukarany więzieniem ${ }^{32}$.

Kto zarządzał biblioteką kapituły w XV wieku? W Gnieźnie wszyscy znani nam z imienia przełożeni biblioteki kapitulnej byli równocześnie prokuratorami (a także oficjałami) kapituły katedralnej. Ponieważ ,prokuratorzy [...] spełniali w imieniu kapituły wszelkie funkcje «związane z finansami i zarządem majątkiem wspólnoty», także liczne obowiązki organizacyjne"33, możemy założyć, że kierowanie biblioteką należało do prokuratora kapituły.

I tak w połowie lat 30. XV wieku bibliotekarzem był Benedykt z Modły ${ }^{34}$. W latach 1457-1458 opiekunem biblioteki był Sędziwój z Czechła ${ }^{35}$. W tymże okresie wykładał on teologię w szkole gnieźnieńskiej i z tym wiązały się wykonywane przezeń obowiązki opieki nad księgozbiorem. Na podstawie jednomyślnego postanowienia kapituły przełożonym biblioteki był w 1490 r. uczony kanonik Jakub Boksica ${ }^{36}$. Po jego śmierci funkcję tę przejął prawdopodobnie Paweł z Zalesia. W 1503 r. funkcję tę pełnił kanonik gnieźnieński, doktor prawa kanoniczne-

${ }^{31}$ Wiesiołowski, Średniowieczne biblioteki wielkopolskie, s. 14.

${ }^{32}$ Korytkowski I, s. 505.

${ }^{33}$ A. Gąsiorowski, Prokuratorzy gnieźnieńskiej kapituly katedralnej w XV w., w: Droga historii. Studia ofiarowane profesorowi Józefowi Szymańskiemu w 70. rocznicę urodzin, red. P. Dymmel, K. Skupieński, B. Trelińska, Lublin 2001, s. 451.

${ }^{34}$ Archidiakon łęczycki, kanonik gnieźnieński, oficjał i wikariusz generalny poświadczony w 1. 1416-1420; 1423-1437, oficjał 1422, prokurator kapituły 1416, 1419, 1421, 1424, 1426-1430, 1433 1436. Gąsiorowski, Skierska, Średniowieczni oficjałowie, s. 76-78; Gąsiorowski, Prokuratorzy, s. 452; Czyżak, Kapituła katedralna w Gnieźnie, s. 317-318.

${ }^{35}$ Sędziwój obserwował sobór w Ferrarze, uczestniczył w soborze w Bazylei, studiował w Paryżu (w 1443 r. był już bakałarzem sentencjariuszem). W 1. 1449-1452 był wikariuszem generalnym gnieźnienskim (nie pełnił funkcji oficjała, jak pisze J. Wiesiołowski). W 1458 r. opuścił kapitułę gnieźnieńską i wstąpił do zakonu kanoników regularnych w Kłodawie. J. Wiesiołowski, Sędziwój z Czechła (1410-1476). Studium z dziejów kultury umysłowej Wielkopolski, „Studia Źródłoznawcze", 9 (1964) s. 75-103; W. Drelicharz, Sędziwój z Czecha h. Korab, PSB XXXVI/1, z. 150 s. 394-399; Czyżak, Kapituła katedralna w Gnieźnie, s. 390-391.

${ }^{36}$ Doktor dekretów, oficjał i wikariusz generalny 1480-1484. „26 X 1482 prosił kapitułę o urlop w funkcjach kanonika i lektora teologii z powodu wyjazdu do Ziemi Świętej”. Gąsiorowski, Skierska, Średniowieczni oficjatowie, s. 81-82. 
go Klemens z Piotrkowa ${ }^{37}$. Z jego osobą wiąże się ciekawa historia. 16 czerwca tegoż roku darował on kapitule napisaną przez siebie księgę rectorale seu librum rectoralis pro ecclesia et choro, za co kapituła ofiarowała mu (na jego usilne prośby) graduał darowany sobie niegdyś przez kardynała i arcybiskupa Fryderyka Jagiellończyka. Równocześnie Klemens wyprosił sobie także antyfonarz z daru tegoż kardynała w dwóch woluminach. W zamian za ten podarunek zobowiązał się przepracować i poprawić w zakresie śpiewu dwa graduały, które spoczywały bezużytecznie w zbiorach kapitulnych. Podkreślał przy tym korzyści, jakie osiągnie stąd zgromadzenie. Po naradach kapituła zdecydowała się podarować Klemensowi księgi, na których tak mu zależało, pod warunkiem, że rzeczywiście zreformuje dwie księgi chórowe ${ }^{38}$.

Antyfonarz i graduał, które wyprosił dla siebie Klemens, zostały podarowane przez arcybiskupa kapitule 30 października 1499 r.: „Ibidem a Rmo dno nostro Cardinali Archiepo duo libri, videlicet Graduale et Antiphonare, sunt portati et dati pro ecclesia Gnezn. et ipsius usu"39.

Niewyjaśnione zostają pobudki, dla których Klemens z Piotrkowa tak gorliwie zabiegał o zdobycie ksiąg ufundowanych przez jego protektora Fryderyka (w 1500 roku po śmierci proboszcza gnieźnieńskiego Jana Gosłubskiego ${ }^{40}$ kardynał mianował Klemensa swoim oficjałem i wikariuszem generalnym). Nie potrafię odpowiedzieć, czy w grę wchodził jego sentyment osobisty, czy też kierował się czymś innym, np. wypełniając jakiegoś rodzaju misję polityczną. Najprawdopodobniejszym jednak wyttumaczeniem zdają się być względy osobiste. Nieprawdopodobne jest raczej, by przedstawiały one jakąś niezwykłą wartość materialną, estetyczną lub muzykologiczną, z której nie zdali sobie sprawy inni członkowie zgromadzenia.

Klemens zajmował się także, na polecenie kapituły, poprawieniem mszału gnieźnieńskiego, który następnie został wydrukowany w oficynie Jana Hallera. 27 kwietnia 1506 r. kapituła potwierdziła, że jest zadowolona z wykonanych prac: „Dni reviso exemplari missalis, per... dnum Clementem de Pyotrkow, decretorum doctorem, ex commisione speciali dnorum emendato et correcto, illud honesto dno Iohanni Haller civi Cracoviensis tradiderunt ad imprimendum, avisantes eun-

${ }^{37}$ Doktor prawa, kanonik gnieźnieński, oficjał i wikariusz generalny gnieźnieński 1500-1503, archidiakon kaliski, prokurator gnieźnieński 1492-1497. Gąsiorowski, Skierska, Średniowieczni oficjałowie, s. 81-82; Gąsiorowski, Prokuratorzy, s. 454.

38 ,Dnus Clemens de Pyotrcow, doctor canonicus ecclesie Gnezn., rectorale seu librum rectoralis, pro ecclesia et choro ecclesie Gnezn. per suam donacionem noviter comparatum, donavit, racione cuius rogavit sibi dari per dnos et donari librum gradualis, quem Rmus olim dnus Cardinalis Archiepus ecclesie donaverat; et dni unanimi voce donaverunt. Item similiter petivit idem dnus doctor a dnis... sibi donari et dari librum antifonarium donacionis eiusdem Rmi dni Cardinalis Archiepi, offerens se duos libros gradualium, qui dudum inutiles in ecclesia Gnezn. iacet, reformare in cantu et reddere ecclesie utiles et pro choro abiles et utiles; et dni iterum deliberati decreverunt donandos, dummodo ipse dnus doctor dictos libros faciet esse utiles ecclesie". Ulanowski 1894, nr 2608.

${ }^{39}$ Tamże, nr 2539.

${ }^{40}$ Prepozyt, wikariusz i oficjał generalny 1484-1500, administrator sede vacante po śmierci Zbigniewa Oleśnickiego (1493). Gąsiorowski, Skierska, Średniowieczni oficjałowie, s. 82-83. 
dem, quod feceret bonam diligenciam, ut correcte et bona littera non caduca imprimeretur, qui se obtulit ad premissa paratum"41.

Klemens z Piotrkowa zmarł w roku 1507. Jak pisał w jego biogramie ks. J. Korytkowski „testamentem przekazał kapitule gnieźnieńskiej m. in. cztery volumina Abbatis Panormitani super decretales. Poprzednio darował był kapitule: „Duos libellos in pergameno notatos et ligatos, unum pro dominis prelatis et canonicis, in quo continentur inceptiones antifonarum, et alium pro scolaribus, in quo continentur versiculi" [dalej wymieniane są różne przedmioty codziennego użyt$\mathrm{ku}$ - PT]. Wykonawcy jego ostatniej woli, Paweł z Zalesia i Maciej Kijowski, kanonicy gnieźnieńscy, złożyli oprócz tego na kapitule 9 V 1509 r. w imieniu zmarłego, dla kościoła metropolitalnego kosztowny antyfonarz in septuplici volumine. Nareszcie w r. 1510 Maciej Kijowski oddał kapitule po zmarłym Liber Evangeliorum et Epistolarum, noviter scriptos et ligatos ac bene reformatos" ${ }^{\prime 2}$.

Przejdę teraz do omawiania księgozbioru kapitulnego. Mimo że, jak wspomniałem, biblioteka kapituły jest tak samo dawna jak sama kapituła, to jednak pierwszą pisemną wzmiankę o istnieniu biblioteki gnieźnieńskiej napotykamy w przywileju arcybiskupa Mikołaja Kurowskiego z 22 października 1404 r. Czytamy tu o erekcji i uposażeniu w katedrze ołtarza pw. Trójcy Świętej i NMP za spokój duszy Piotra z Zawichostu, mistrza dekretów, prokuratora konsystorza gnieźnieńskiego. Był on dobroczyńcą katedry, łożył znaczne ofiary na utrzymanie budynku, a także zapisał jej bibliotece znaczny księgozbiór treści prawniczej. W przywileju wymienione są następujące dzieła:

Decretales cum aparatu Innocencii IV et cum casibus

Sextus cum glossis ordinariis

Clementinae cum glossis ordinariis

Summa dni Hostiensis tria volumina

Glossae ordinariae decretorum

Casus Bernhardi in terminie super librum decretalium

Aureum repertorium magistri Wilhelmi speculatoris per omnes titulos et rubricas decretalium

Liber conclusionum et decisionum rote Curie Romane

Liber de censura ecclesiastica Johannis de Lignano

Johannis Baldi decreta una cum distinccionibus eorundem in multis materis Juris canonici

Liber questionum dni Briviensis

Liber de regulis Juris libri sexti ${ }^{43}$.

Następna wzmianka pochodzi z 8 marca 1412 r. W aktach kapitulnych zapisano wówczas deklarację proboszcza katedralnego Mikołaja Strosberga ${ }^{44}$, że u siebie w domu miał librum decretalium et librum Sexti i kielich będące własnością

\footnotetext{
${ }^{41}$ Ulanowski 1894, nr 2646.

${ }^{42}$ Korytkowski III, s. 220-221.

${ }^{43}$ Korytkowski I, s. 502.

${ }^{44}$ Czyżak, Kapituła katedralna w Gnieźnie, s. 374-375.
} 
kościoła ${ }^{45}$. Odtąd wzmianki poświęcone bibliotece pojawiają się w aktach kapitulnych już regularnie. 24 kwietnia 1420 r. na posiedzeniu generalnym zanotowano, jakie książki zostały wyniesione z biblioteki i u kogo się one aktualnie znajdują: „Memoriale librorum ecclesie Gnezn. alienatorum: Pastorale b. Gregorii ecclesie Gezn. habet Szathwath; item cronicam Martinianam habet dnus Wincentius archidiaconus Unieoviensis; item quoddam volumen Henricus plebanus in Stronsko recepit post mortem prepositi dicti Cappa"46

Odnośnie kroniki Marcina Polaka (Chronica Martiniana ${ }^{47} \mathrm{w}$ najdawniejszym katalogu bibliotecznym z r. 1608 uczyniono uwagę, że drogocenny ten kodeks zaginął u Wincentego, archidiakona uniejowskiego i kanonika gnieźnieńskiego.

22 grudnia 1422 r. szlachcic Paszko, marszałek dworu zmarłego arcybiskupa Mikołaja Trąby, zwrócił kapitule jego pieczęcie, których nie miano już używać oraz jedną księgę - pontyfikał ${ }^{48}$.

W znaczący sposób bibliotekę kapitulną zasilił legatem testamentowym archidiakon gnieźnieński, kanonik i wikariusz generalny poznański Mikołaj Kicki (Kiczka, Kyczka, zwykle zwany de Kiky albo de Kiki), padewski doktor dekretów, jedna $\mathrm{z}$ najwybitniejszych osobistości w kapitule swego czasu ${ }^{49}$. Kapituła gnieźnieńska wzbogaciła się dzięki niemu o znaczną liczbę rzadkich dzieł, głównie z zakresu prawa. Szczególnie cenne były akta soboru w Konstancji.

Testament Kickiego jest niezwykle interesującym, niebanalnym dokumentem, odbiegającym w swej formie od zwykłego wyliczenia darowywanych przedmiotów. Jego niecodzienność polega na tym, że donator programuje tu precyzyjnie przyszłość zarówno książek, jak i osób nimi obdarowanych. Przede wszystkim Kicki w swoim testamencie zastrzegł wyraźnie, ażeby legowane przezeń księgi nie były wypożyczane z biblioteki nikomu, jeżeli wpierw nie wpłaci kaucji w wysokości podwójnej ich wartości w złocie lub w srebrze. Mimo tej ostrożności zaledwie kilka $\mathrm{z}$ wymienionych ksiąg zachowało się w bibliotece kapituły. Między innymi przed rokiem 1608 zaginęły wspomniane akta soborowe. Świadczy o tym uwaga w najstarszym zachowanym katalogu biblioteki. Co ciekawe, jedno z podarowanych kapitule dzieł (Dystynkcje) znajdować się miało u słynnego uczonego Pawła Włodkowica. W rozmowie z egzekutorem testamentu zaprzeczył on jednak, że je posiada.

Oddzielnie zapisał Kicki dla lektora prawa kościelnego przy szkole gnieźnieńskiej spisane własnoręcznie przez siebie oryginalne dzieło Wawrzyńca de

${ }^{45}$ Tamże.

${ }^{46}$ Ulanowski 1894, nr 1562; Korytkowski IV, s. 305-306.

${ }^{47}$ M. Polak, Kronika papieży i cesarzy, wyd. A. Fabiańska, J. Soszyński, Kęty 2008. Na temat tego dzieła zob. J. Soszyński, Kronika Marcina Polaka i jej średniowieczna tradycja rękopiśmienna w Polsce, Warszawa 1995; tenże, Sacerdotium-imperium-studium. Władze uniwersalne w późnośredniowiecznych kronikach martynikańskich, Warszawa 2006.

48 „Nobilis Paszko, olim marszalcus dni Arepi, presentavit (...) item unum librum pontificalem (...)". Ulanowski 1894, nr 1584.

${ }^{49}$ Zob. P. Dembiński, Wykształcenie prałatów i kanoników poznańskiej kapituły katedralnej schyłku wieków średnich, w: Fontes et historia, Poznań 2007, s. 58; Czyżak, Kapituła katedralna w Gnieźnie, s. 367-368. 
Pinnis (Lectura super decreta). Z książki tej Kicki sam korzystał prawie 20 lat prowadząc wykłady i tradycja ta miała zostać zachowana w przyszłości. Kolejną ciekawostką tego legatu jest ostatni zapis na rzecz krewnego (filiaster). Miała mu przypaść pewna ilość ksiąg prawniczych, pod tym jednakże warunkiem, że musi on poświęcić się nauce prawa. W przeciwnym razie księgi prawa kanonicznego bezwarunkowo przejść miały na własność kapituły gnieźnieńskiej ${ }^{50}$. Gwarantem wykonania tej części testamentu został Jan Lychiński. Sprawować miał on pieczę nad księgami i gdyby ów młody krewny rozpoczął studia prawa kanonicznego, w pierwszym roku otrzymać miał od Lychińskiego Decretale, w drugim roku $\mathrm{Li}$ ber Sextum i Klementyny. Po sześciu latach studiów, gdyby okazał się mężem wytrwałym, nie rozpustnym, miał otrzymać resztę zapisanych sobie ksiąg.

Przeznaczone jej księgi przekazał kapitule 30 kwietnia 1435 r. wykonawca testamentu Mikołaja Kickiego, dziekan gnieźnieński Jan. Oddane zostały one pod opiekę bibliotekarza Benedykta z Modły, kanonika i oficjała gnieźnieńskiego. Poniżej podaję szczegółowy spis:

„Item libri infrascripti sunt isti per vener. dnum Nicolaum archidiaconum dictum Kyczka pro ecclesia Gnezn. testamentaliter legati et per vener. virum dnum Iohannem decanum Gnezn. tamquam executorem dicti testamenti in dicta ecclesia Gnezn. coram suprascriptis et coram me Adam ipsorum notario in capitulo generali repositi et in magna cista per dnum Benedictum officialem servati [signati]:

Et primo liber Decretorum

Item Rosarium super Decretum

Item directorium super officium inquisicionis

Item Novelle in uno volumine super primum et secundum librum

Item super tercio, quarto et quinto in alio volumine

Item tercio volumine super sexto libro Decretalium

Item rationale divinorum officiorum ${ }^{51}$

Item lectura super sexto Decretalium dni Dominici

Item lectura super Clementinas dni Francisci

Item lectura super secundo Decretalium dni Anthonii de Butrio

Item lectura quinto eiusdem dni Anthonii, circa quam in uno volumine continentur plurium Decretalium repeticiones, necnon tractatus Iohannis Calderini de interdicto ecclesiastico, tractatus Iohannis de Lignano de censura ecclesiastica, de iusto bello, necnon consilia dni Anthonii de Butrio et alia pulcra notabilia

Item duo volumina distinccionum [inna lekcja u Korytkowskiego: declarationum] Henrici Bogii, que sunt apud mgrum Paulum Wladimiri, pro quibus requisitus fuit per dnum Iohannem decanum Gnezn. et ipse negat se ea habere

Item summa Gothfridi

Item acta concilii Constanciensis

Item Lectura dni Laurenciis de Pinis super Decreto, quam ipse scripsit propria manu et de ipsa legit in scoliis

${ }^{50}$ Korytkowski II, s. 247-248.

${ }^{51}$ Symboliczno-alegoryczny wykład liturgii autorstwa Wilhelma Duranda ( $\left.\uparrow 1296\right)$, rozpowszechniony w całej Europie już przed rokiem 1500 w 44 wydaniach. L. Hajdukiewicz, Biblioteka Macieja z Miechowa, Wrocław 1960, s. 309. 
Disposicio prefati dni N. Kyczka archidiaconi Gnezn. etc. Disposicio tamen et mee extat voluntatis, quod dicti libri assignentur in libraria ecclesie Gnezn. et nulli commodentur extra librariam, nisi deposito pignore dupli valoris in pecunia, auro vel argento.

Item ex quo prebenda in ecclesia Gnezn. disponitur pro lectore in iure canonico, lego pro eadem ecclesia lecturam super Decreto in longis quinternis papiri regalis, que est de compilacione peritissimi et suo tempore famosissimi viri dni Laurencii de Pynu [Pinnis], quam propria manu conscripsit et recollegit et de ipso Decretum in scolis legit fere XX annis, que merito debet conservari, cum sit originalis et fontalis, de qua studiosus lector, habitis de ea remissionibus, poterit opus utilissimum fabricare.

Pauper scolaris Iacussius Gardzyne: Item pro Iacussio de Kyky filiastro paupere scolari et orphano lego: Decretales maiores, que non sunt preciose; item Clementinas; item Speculum iudiciale in pargameno; addiciones Iohannis Andree super Speculo predicto similiter in pargameno; item lecturam Hostiensis super tercio, quarto et quinto libro in papiro regali; item pro eodem Iacussio lego et deputo volumen, in quo sunt consilia Lupi de Castelliono et statuta [studii] Paduani in cartis medianis; item volumen, in quo est repertorium Petri de Parusio cum aliis tractatibus in papiro minori; item volumen, in quo est repertorium super Decretum et tractatus Iohannis Calderini de ecclesia interdicto, necnon Iohannis de Legis(s) de censura ecclesiastica et iusto bello et aliis pulcris similiter in papiro minori; item volumen similiter in papiro minori, in quo continentur dicta Baldi, seu addiciones super Innocencio, super Novella Sexti et super Speculatore cum repeticionibus capitulorum vestra(s) de cohabitacione clericorum et mulierum et capitulo ultimo de causa posse et proprietatis; item rethoricam Tulii in pargameno in coopertorio ligato; item Allanum de planctu nature in pargameno; item Gracismum in pargameno; item formularium in pargameno de stillo secularie pulcris et ornatis formis $^{52}$; item reportata seu notata brevia super Vito libro Decretalium in pargameno et in coopertorio in pargameno.

Ultima disposicio: Volo autem et ita dispono, quod dicti libri tradantur ad manus dni Iohannis Lychinsky et per eum conserventur, quosque Iacussius, si erit aptus, studebit in iure canonico, ita, quod primo anno studii incipiendi sibi Decretale det, post II annos sibi Sextum et Clementinas tradat, sed postquam perficiet annum sextum studii sui et erit vir stabilis, non discolus, sibi alios libros assignet; de Allano, Gracismo, Tulii rethorica assignet, quando placet. Si vero dictus Iacussius studere nolverit, extunc volo, quod libri iuris canonici pro ecclesia Gnezn. per ipsum dnum Iohannem Lychinsky assignentur sine difficultate" ${ }^{93}$.

3 lutego 1449 r. Jakub z Dębna ${ }^{54}$, dziekan gnieźnieński, kanonik krakowski i poznański, brat arcybiskupa Wincentego Kota z Dębna ${ }^{55}$, po jego śmierci zwrócił

\footnotetext{
${ }^{52}$ Formularz sporządzania pism urzędowych i listów.

${ }^{53}$ Ulanowski 1894, nr 1646.

${ }^{54}$ Czyżak, Kapituła katedralna w Gnieźnie, s. 327-328.

${ }^{55}$ S. Hain, Wincenty Kot prymas Polski 1436-1448, Poznań 1948.
} 
kapitule pożyczone niegdyś przez tegoż arcybiskupa rękopisy treści prawno-kanonicznej. Najprawdopodobniej znalazły się one w przekazanym mu legacie ${ }^{56}$.

15 czerwca 1450 r. sporządzono spis kosztowności znajdujących się w skarbcu katedralnym. Wśród kosztowności spisano także księgi. Znajdujemy tu trzy wielkie mszały z darów arcybiskupa Wojciecha Jastrzębca ${ }^{57}$, kanonika Mikołaja Słupka $^{58}$ (zachowane, iluminowane) i dziekana Jaśka z Czechła ${ }^{59}, 13$ mniejszych mszałów, 5 legendarzy, 4 antyfonarze, w tym dwa dawne, następnie 5 psałterzy (dwa z daru arcybiskupa Wincentego Kota, trzy darowane przez kanclerza Mikołaja Górkę), księgę homilii, księgę prefacji, kapitularz de scriptura Italica, agendę z kalendarzami i ewangeliarz. Służyły one wystawnej uroczystej liturgii, a ranga ofiarodawców pozwala oczekiwać wysokiego poziomu wykonania, co znajduje potwierdzenie w zachowanych egzemplarzach.

Spis ten w swojej części „książkowej” wygląda następująco:

„In primis tria missalia maiora: unum de dono dni Iastrzambyecz, secundum de dono dni Iaschkonis decani Gnezn. et tercium de dono dni Slupkonis

Item alia XIII minora communia

Item quinque legendaria per circulum anni

Item quatuor antiphonaria: duo nova et duo antiqua

Item omelie quadragesimales

Item liber prefationum cum Venite de nota

Item antiquum capitulare de scripta ytalica

Item quinque psalteria: duo data per dnum Vincencium et tria per dnum Gorkam

Item agendare cum duobus antiquis kalendaribus

Item liber Ewangeliorum et Epistolarum cum reliquiis" ${ }^{60}$

56 „Dnus Iacobus de Dambno decanus libros tres ecclesiasticos iuris canonici, scilicet Decretum, Sextum et Clementinas dive memorie Rmo petri dno Vincencio Archiepo Gnezn. per capitulum mutuatos... restituit in effectu". Ulanowski 1894, nr 1770; Korytkowski II, s. 310.

${ }^{57}$ G. Lichończak-Nurek, Wojciech herbu Jastrzębiec, arcybiskup i mąż stanu, Kraków 1996.

${ }^{58}$ Czyżak, Kapituła katedralna w Gnieźnie, s. 360-361.

${ }^{59}$ Notariusz publiczny, kanonik poznański i krakowski, kanonik i dziekan gnieźnieński kanclerz biskupa krakowskiego Wojciecha Jastrzębca, delegat na sobory w Konstancji i Bazylei, posiadacz interesującej biblioteczki. Zob. Wiesiołowski, Sędziwój z Czechła, s. 77-78; Czyżak, Kapituła katedralna w Gnieźnie, s. 336-337.

${ }^{60}$ Ulanowski 1894, nr 1793. Jak informuje wydawca „powyższy inwentarz zachował się na dwóch kartach pergaminowych, które znajdują się przy kodeksie Sędziwoja z Czechła (Muzeum ks. Czartoryskich nr 1310, f. 946-947)”. Zob. także wyd. W. Kętrzyńskiego, MPH, t. V, Lwów 1888, s. 949-954. Na temat samego kodeksu Sędziwoja por. prace W. Drelicharza, Annalistyka małopolska XIII-XV wieku. Kierunki rozwoju wielkich roczników kompilowanych, Kraków 2003, s. 410-418; Źródta i autor rocznika Sędziwoja. Z dziejów kultury historycznej duchowieństwa wielkopolskiego w XV w., „Nasza Przeszłość”, 80 (1993) s. 131-167; Wstęp do studium źródtoznawczego „Rocznika Sędziwoja”, „Studia Historyczne”, 35 (1992) z. 3, s. 291-306; Problem tzw. kontynuacji „Rocznika Sędziwoja”, „Studia Historyczne”, 36 (1993) z. 2, s. 141-147; Treści ideowe „Rocznika Sędziwoja”, „Kwartalnik Historyczny”, 99(1992) s. 49-63, a także J. Wiesiołowskiego, Kolekcje historyczne w Polsce średniowiecznej XIV-XV wieku, Wrocław-Warszawa-Kraków 1967, s. 98-135. 
W aktach kapitulnych znajdujemy także dowody dbałości kanoników o swój księgozbiór. 9 XII 1451 wydano polecenie, ażeby każdy prałat i kanonik w przeciągu 14 dni zwrócił do biblioteki pożyczone z niej księgi. Przeciwko uchylającym się od tego obowiązku podjęte miały zostać odpowiednie kroki prawne. Sankcje trwać miały tak długo, dopóki książki nie zostaną oddane. Na przyszłość każdy wypożyczający książkę powinien najpierw złożyć jako zastaw sumę pieniężną odpowiadającą wartości pożyczanej książki. Wypożyczenia mogły odbywać się odtąd jedynie za zgodą kapituły: „Dni prelati et canonici tractantes de commodo et rebus capituli decreverunt, quod unusquisque prelatorum et canonicorum huiusmodi ecclesie, qui libros ecclesie retinet, ut infra XIIII dies eosdem restituat et reponat, alias contra detentores et observantes libros ecclesie decreverunt processus tamdiu, donec restituent, et statuerunt, quod nullus dnorum libros ecclesie de thezauro recipiet, nisi dnorum de capitulo consensu et licencia obtentos, et alias recipiens ponet vadium sive pignus in valore libri sive librorum recipiendorum" 61 .

Podobną akcję przeprowadzono cztery lata później. Widocznie dekret z $1451 \mathrm{r}$. nie odniósł oczekiwanych skutków, gdyż 30 października 1455 r. został on ponowiony, tym razem jednak w znacznie ostrzejszej formie. Wszyscy, którzy wypożyczyli księgi z biblioteki kościelnej, wezwani zostali do ich okazania na posiedzeniu kapituły w oznaczonym dniu. Pierwsze zdanie odnośnej zapiski ma bardzo ostre, prawnokarne brzmienie. Oprócz tej prawniczej formuły zapiska zawiera także spis książek, które prezentowali wezwani kanonicy i prałaci. I tak Piotr Pniewski okazać musiał Decretales i Decretum, Jan Nepos Brzostkowski ${ }^{62}$ Decretales i De Vita Christi, ponadto książeczkę dotyczącą pokuty i jałmużny, a także - co ciekawe - jakąś książkę heretycką, zaś Jan Furman ${ }^{63}$ Apokalipsę z glosą, św. Augustyna oraz listy św. Hieronima. Najwięcej wypożyczeń miał na swoim koncie Sędziwój z Czechła. Czytał on głównie literaturę prawniczą i teologiczną. Oto szczegółowy spis: „Dni prius contra omnes tam de gremio dnos, quam alias personas, libros ecclesie detinentes, processum monitorium decreverunt, ut infra certos dies presertim pro die superius notata in capitulari se cum eisdem representarent, dni ver inferius descripti monicioni parentes libros infrascriptos representaverunt. Et primo dnus Petrus Pnyewsky prepositus et officialis presentavit Decretales et Decretum. Item dnus Iohannes de Brzosthkowo cantor representavit Decretales et librum de Vita Christi. Item mgr Santco statuta provincialia; item librum sentencie diversorum doctorum; item Lunam salutis; item librum de Vita Christi in papiro; item kalendare; item legendas sanctorum; item statusta provincie Ma-

${ }^{61}$ Ulanowski 1894, nr 1805.

${ }^{62}$ Kantor gnieźnieński, administrator sede vacante po śmierci Wojciecha Jastrzębca (1436), oficjał i wikariusz generalny 1437-1438, 1440-1441, 1449-1450, 1454-1456, prokurator kapituły 1432. Gąsiorowski, Skierska, Średniowieczni oficjatowie, s. 78-79; 80; Gąsiorowski, Prokuratorzy, s. 452; Czyżak, Kapituła katedralna w Gnieźnie, s. 335-336.

${ }^{63}$ Jan Furman z Zaniemyśla, oficjał warszawski ok. 1438-1440, kustosz i prokurator gnieźnieński. Zob. P. Dembiński, Wykształcenie prałatów i kanoników poznańskiej kapituły katedralnej schytku wieków średnich, w: Fontes et historia, Poznań 2007, s. 64; Gąsiorowski, Prokuratorzy, s. 453; Czyżak, Kapituła katedralna w Gnieźnie, s. 341-342. 
guntinensis; item librum de papistis cum ymaginibus pictis; item librum de Vita Christi; item Iacobum de Voragine in capitulari representavit. Item dnus Iohannes Furman custos Gnezn. Apocalipsim cum glosa presentavit; item librum Augustini super Epistolas; item epistolas Ieronimi in capitulari presentavit. Item dnus Iohannes Nepos libellum de penitencia, elemosina et oracione; item libellum suspectum hereticorum coram dominis presentavit" ${ }^{\prime 64}$.

Sędziwój z Czechła był interesującą postacią. 10 VIII 1458 r. zrzekł się kanonii, aby resztę świątobliwego żywota spędzić w zaciszu klasztoru kanoników regularnych laterańskich w Kłodawie. Zwrócił wówczas kapitule pożyczone z jej biblioteki 12 dzieł treści prawniczej i teologicznej. Równocześnie podał jej wykaz ksiąg kapitulnych wypożyczonych innym osobom. Wskazywałoby to, że to Sędziwój zajmował się w tym czasie biblioteką ${ }^{65}$. I tak jedną z ksiąg (Speculator ${ }^{66}$ ) wypożyczono opatowi klasztoru trzemeszeńskiego do przepisania. Zbigniew Oleśnicki wypożyczył dwie książki: patriarchę bez tytułu (Patriarcha Constantinopolitanus Jakuba z Vitriaco?) oraz Historię kościelna (Euzebiusza z Cezarei lub też Piotra Komestora). Książki te widziane być miały u Jana Długosza lub jego krewnego. Wreszcie arcybiskup Wincenty Kot wypożyczył św. Augustyna super Iohannem, która to książka znajdować się miała natenczas u jego brata, Jakuba. Najwidoczniej nie zwrócił on Augustyna w roku 1449, oddając kapitule trzy inne książki wypożyczone przez Wincentego. Nie wiadomo przy tym, czy chodzi tu o homiletyczny komentarz do pierwszego listu św. Jana Apostoła (In epistolam Joannis tractatus), czy też może o opracowany w 124 homiliach komentarz do Ewangelii (In Joannis Evangelium tractatus):

„Item die Lune X m. Augusti... vener. dni Jacobus de Dambno decanus, Iohannes de Brzosthcowo cantor, Michael de Lassothky scolasticus, Iohannes de Brzosthkowo nepos, Nicolaus de Cyechel in decretis licentiatus, vicarius in Spiritualibus et officialis generalis, Petrus Barthsky et Benedictus Furman, prelati et canonici, fuerunt capitulariter congregati, coram quibus personaliter comparens vener. mgr Santco, condam canonicus Gnezn., ultimatim in monasterium in Clodawa religionem et ordinem recepturus se procurans, libros de ecclesia commodatos reposuit et representavit, qui inferius sequentur: inprimis primam partem summe b. Thome in pergameno; item quatuordecim libri b. Augustini de Civitate Dei in uno volumine in pergameno scripti; item librum $b$. Augustini de verbis apostoli in pergameno; item Passionale XII apostolorum in pergameno; item duas partes de Vita Christi; item duas partes summe Hostiensis in papiro; item quadraginta omelias b. Gregorii communes in pergameno; item Catholicon in papiro; item librum Variarum Cassiodori in pergameno; item Iacobinum de Sanctis; item tres partes lecture super Matheum olim mgri Stephani Palecz; item Passionale parvum in pergameno, dictum Aurea legenda, quod dnus Io. de Brzosthcowo cantor commodavit ad corrigendum suum sub spe restitutionis" ${ }^{\prime 67}$.

${ }^{64}$ Ulanowski 1894, nr 1852.

${ }^{65}$ Korytkowski I, s. 173-176.

${ }^{66}$ Być może chodziło tu o Speculum iuris Wilhelma Duranda lub też Speculum Humanie salvationis Honoriusza z Autun, czy Speculum animae peccatricis Jakuba de Gruytrode.

${ }^{67}$ Ulanowski 1894, nr 1880. 


\section{Ibid.}

Item mgr Santco demonstravit librum Speculatorem ecclesie Gnezn. aput abbate in Tremeschna commodatum ad rescribendum. Item dixit, quod bone memorie Rdus pater dnus Sbigneus d. g. Cardinalis Epus Crac. mutuaverat hic de ecclesia duos libros: unus intitulatur Patriarcha et alius Ecclesiastica historia, videndi sunt aput dnum Dlugossium aut prepositum Crac. et Gnezn. suum nepotem. Item dixit, quod bone memorie dnus Vincencius Arepus de ecclesia commodaverat librum: Augustinum super Iohannem, videndus est aput dnum Iacobum decanum Gnezn. fratrem suum" 68 .

Sędziwój z Czechła był szanowany za swą uczoność w dziedzinie prawa, z tego też powodu otrzymał dwa legaty książkowe: jeden na mocy testamentu swego krewnego, wspomnianego już powyżej dziekana gnieźnieńskiego Jaśka z Czechła, drugi zaś od licencjata dekretów Uniwersytetu Krakowskiego Mikołaja Czechelskiego. Sędziwój jednak żadnej z tych darowizn nie przyjął. 24 kwietnia 1465 r. arcybiskup Jan Gruszczyński, za radą prałatów i kanoników kapituły, zgodził się na jego prośbę, przedłożoną osobiście, aby oba legaty przeszły na własność kościoła gnieźnieńskiego: „Honor mgr Santco, prepositus in Clodawa, suis in manibus testamentum, instrumentaliter per bone memorie dnum Iaskonem condam decanum Gnezn. factum, habens et tenens per prefatum Rmum dnum Archiepum petivit ratificari et confirmari et ad percepcionem librorum iuris canonici et aliorum in dicto testamento dni Iassconis decani descriptorum admitti; et dnus Archiepus de consilio dnorum prelatorum et canonicorum ipsum testamentum ratificavit... ad recepcionemque legatorum librorum admisit. Qui mgr Santco de libris per bone memorie dnum Nicolaum Cyechelsky, in decretis licenciatum, Universitati Crac. legatis noluit nec vult se interponere, nec vult eorum usum habere" ${ }^{99}$.

Pięć lat później jednak Sędziwój zmienił zdanie. 12 czerwca 1470 r. pojawił się w kapitule gnieźnieńskiej jego pełnomocnik, Mikołaj Szczepankowski, pleban w Mąkołynie, który prosił o wydanie na potrzeby prepozyta kłodawskiego z książek Jaśka Dekretałów Franciszka Zabarelli. Prośbę tę kapituła spełniła: „Dnus Nicolaus Sczepankowsky plebanus in Mankolyno nuncius vener. et egregii mgri Sandivogii prepositi Clodaviensis in vim credencie eiusdem dnis misse recepit a dnis de capitulo et de manibus dni Nepotis, canonici ecclesie et procuratoris capituli Gnezn., libros olim dni Iaszkonis decani Gnezn., videlicet lecturam super primam partem decertalis (s) Francisci de Barasellis (s) in papiro, de quo libro capitulum in vim dicte credencie nomine dni prepositi in Clodawa prefata per presentes quittavit"70.

23 października 1460 r. kapituła gnieźnieńska uchwaliła statut de leccionibus audiendis, w którym postanowiła, że jej członkowie mogą wypożyczać książki potrzebne im do nauki. Jak pisze Krzysztof Stopka ,chodziło tu z pewnością o ka-

\footnotetext{
${ }^{68}$ Tamże, nr 1881.

${ }^{69}$ Tamże, nr 1974.

${ }^{70}$ Tamże, nr 2033.
} 
noników, będących słuchaczami kursu teologiczno-prawniczego"71. Bez wątpienia należy przychylić się do jego opinii.

W tym też czasie zaostrzono przepisy dotyczące wypożyczeń. Każdy wypożyczający musiał dopełnić pewnych warunków: zapisać się do akt kapitulnych (metryki) z wymienieniem książek i zobowiązaniem ich zwrotu oraz wykazać się na kapitułach generalnych, jakie książki odebrał. Niezwrócenie ich w odpowiednim terminie zagrożone było karą klątwy kościelnej ${ }^{72}$. „Dni... habendo tractatum de leccionibus audiendis decreverunt et statuerunt, quod fratres de gremio libere possunt recipere libros ecclesie pro audiendis leccionibus et quod quilibet recipiens librum vel libros inscribet se ad matricam, recognoscendo, quos recipit, et de restituendo, ita, quod recipiens libros, unus vel plures, quilibet sub pena tenebitur representare in singulis generalibus capitulis et ostendere dnis, quales libros commodavit vel recepit et ostensione dnis facta, si ulterius indiguerit eisdem, poterit recipere pro studio suo, et iterum tenebitur restituere eosdem ad thezaurum sub pena et censuris ecclesiasticis" $" 73$.

Ciekawym dokumentem jest zapis testamentowy, jaki na rzecz kapituły gnieźnieńskiej uczynił biskup krakowski Tomasz Strzempiński ${ }^{74}$. Rejestr podarowanych przezeń książek został wciągnięty do metryki kapitulnej 29 października 1461. Było to 26 cennych woluminów prawniczych i teologicznych, w tym zdobiony złotem mszał (?). O wielu książkach dowiadujemy się, że były oprawione w skórę (białą lub kolorową), niektóre jednak pozostały nieoprawne, jak lectura super primo libro Decretalium, mająca formę niezszytych seksternów. Niemal o wszystkich także wiemy, ile biskup za nie zapłacił. Były to bowiem jego prywatne książki, z których korzystał na własne potrzeby. Lecture super Clementinas były nawet w pewnej części własnoręcznie przez niego spisane, Sentencje zaś glosowane (najprawdopodobniej w czasie studiów). Podaję tutaj cały wykaz:

„Registrum librorum per bone memorie dnum Thomam Strzampinsky Epum Crac. ecclesie Gnezn. legatorum sequitur per ordinem.

Secuntur conscripta librorum per bone memorie Rmum patrem dnum Thomam de Strzampino Epum Crac. in ultima sua voluntate pro ecclesia Gnezn. legatorum et manu propria conscriptorum sub hac, qua sequitur, forma.

Item primo pro ecclesia Gnezn., a qua plura recepi beneficia, lego et dono Secundam secunde $b$. Thome de Aquino novam in pergameno, comparatam per me

${ }^{71}$ K. Stopka, Szkoły katedralne metropolii gnieźnieńskiej w Średniowieczu. Studia nad kształceniem kleru polskiego w wiekach średnich, Kraków 1994, s. 130; J. Rył, Biblioteka Katedralna w Gnieźnie, cz. I, ABMK, 32 (1976) s. 195, p. 109 błędnie sądzi, że chodziło tu o książki dla prowadzących wykłady kanoników.

${ }^{72}$ Korytkowski I, s. 503.

${ }^{73}$ Ulanowski 1894, nr 1914.

${ }^{74}$ Wiele miejsca poświęcił biskupowi T. Strzempińskiemu w swych dziełach Jan Długosz. Por. Rozbiór krytyczny Annalium Poloniae Jana Dlugosza z lat 1445-1480, t. 2, Wrocław-WarszawaKraków 1965, s. 134. Zob. też Potkowski, Ksiązka rękopiśmienna, s. 185-187; Hornowska, Zdzitowiecka-Jasieńska, Zbiory rękopiśmienne, s. 144-152; J. Zathey, Biblioteka Jagiellońska w latach 1364-1492, w: Historia Biblioteki Jagiellońskiej, t. 1: 1364-1775, J. Zathey, A. Lewicka-Kamińska, L. Hajdukiewicz, pod red. I. Zarębskiego, Kraków 1966, s. 96-100. 
pro XX marcis 6 gr, que est aput dnum Iohannem Epum Pozn. sibi commodata per me.

Item lego eidem ecclesie Gnezn. IV volumina in papiro, in quorum uno ponitur scrutinium scripturarum Pauli Epi Burgensis contra errores Iudeorum cum Mandagoto glozato de electione. In secundo volumine ponuntur IV articuli Bohemorum disputati in concilio Basiliensi, quem habet doctor Stanislaus de Kobylino. In aliis duobus voluminibus sermones ad clerum facti in concilio eodem: unum in rubea, aliud in alba citerna pellibus; pro XXX flor. omnia IV volumina.

Item flores b. Gregorii in pergameno pro tribus marcis mediorum gr.

Item flores b. Bernardii pro III flor. in papiro in alba pelle

Item Liram super Ewangelia cum exposicione Gorram super canticos, in alba pelle, pro II marcis in papiro

Item Liram super Epistolas pro II marcis

Item lecturam super primo libro Decretalium in sexternis non ligatis pro VIII flor.

Item sexternos lecture super Clementinas de manu mea usque ad medium fere et super quarto libro Decretalium de alia manu, qui iam sunt ligati ad asseres in rubea pelle consumptibus Alberti de Lyssecz Decretorum doctoris

Item lecturas super tercio et secundo et quarto Sentenciarum in parvis tribus libellis in albis pellibus cum metris distinccionum glozatis de manu mea

Item textus Sentenciarum in papiro

Item omeliare per circulum anni dominicalium sermonum et de Sanctis in papiro pro III marcis

Item sermones in tribus parvis libellis de modo Francie pro V flor.

Item duo volumina Iacobini sermonum de Sanctis et duo alia volumina Iordani sermonum dominicalium per circulum anni in papiro pro XXII flor.

Item summa Pisani in papiro pro IV marcis in alba pelle

Item sermones mgri Stanislai de Skarbimiria in rubea pelle pro IV marcis

Item Milicii sermones per circulum anni et de Sanctis in eodem volumine ad clerum in papiro pro III marcis

Item quadragesimale per auctoritates sanctorum doctorum pro 3 marcis

Item conclusiones b. Thome super Sentencias in papiro pro IV flor., que egent correccione

Item mensale (missale?) cum auro intextum novum, quod dono pro maiori altari Item practicam Albici in papiro

Item parvum libellum super cantica in pargameno

Hec omnia suprascripta lego et dono testamentaliter pro ecclesia metropolitana Gnezn. in remissionem peccatorum meorum et in recompensam beneficiorum receptorum ab ea, salva semper revocatione, de qua supra, de qua debet constare per scripturam de manu mea vel per aliam scripturam autenticam aut legitimum documentum"'75.

\footnotetext{
${ }^{75}$ Ulanowski 1894, nr 1924; Korytkowski IV, s. 36.
} 
23 kwietnia 1464 r. bracia zmarłego arcybiskupa Jana Sprowskiego przekazali kapitule różne kosztowności, w tym książki (dwie z nich zostały wcześniej przez Sprowskiego wypożyczone): ,Item novum librum omeliarum in pargameno bona scriptura scriptum et in asseribus dispositum introligatum. Item pontificale novum. Item duas partes sive duo volumina Speculi hystorialis per ipsum dnum Archiepum donatos representaverunt. Item aliud pontificale et librum Pantheon ecclesie restituerunt" 76 .

Wśród skarbów i relikwii kapituły gnieźnieńskiej (Inventarium sanctuarium et rerum ecclesie), które spisano 9 stycznia 1468 r., znalazła się też jedna księga - Item liber Evangeliorum in toto scriptus auro cum ymaginibus ${ }^{77}$. Tego samego dnia spisano rejestr kosztowności odbieranych ze skarbca zamku uniejowskiego. Znalazły się nim m. in. następujące pozycje: Decretum. Item Decretales. Item liber Sexti feria tercia ante festum b. Iacobi Apostoli ${ }^{78}$. Wynika stąd, iż przeprowadzono wówczas inwentaryzację skarbca w Gnieźnie oraz drogocennych przedmiotów, które wywożono przed zagrożeniem do Uniejowa i które w początku $1468 \mathrm{r}$. powróciły do stolicy metropolii.

15 października tego samego roku prokurator Benedykt Furman (podówczas prokurator gnieźnieński) na posiedzeniu kapituły przedstawił cztery książki, które przyjęte zostały na własność biblioteki kapitulnej po śmierci kanonika Piotra Bardskiego. Były to dwie książki prawnicze: Decretales oraz jakiś zbiór kazusów (w okładce, ale bez skórzanej oprawy), druga część żywota Chrystusa, a także książka teologiczna bez tytułu, określona incipitem: „Dnus Benedictus Furman canonicus et procurator capituli ecclesie Gnezn. libros, post mortem olim Petri Bardsky receptos, dnis presentavit videlicet: Decretales; item alium, secundam partem vite Christi; tercium, casum in terminis in asseribus sine cutis tectura; item quartum librum theologicalem, qui incipit: „Rdo patri dno Guiliamo d. g. Epo Senoniensi"79.

Kolejnym dowodem dbałości kapituły o własny księgozbiór jest zapisek z 21 października 1471 r. Wydelegowano wówczas kanonika Marcina z Niechanowa (późniejszego prokuratora kapituły w 1. 1479-1480), by odebrał od arcybiskupa Gruszczyńskiego zestaw książek prawniczych, które niegdyś wypożyczył jego zmarły właśnie krewny, doktor Marcin. Na pokrycie kosztów podróży Niechanowski otrzymał jedną grzywnę. „Dni dno Martino de Nyechanovo, canonico Gnezn., fratri suo, deputaverunt I marcam pro eo, quod portavit libros a Rmo dno Archiepo videlicet Decretum, Decretales, Sextum et Clementinas, quod olim dnus Martinus doctor, dni Archiepi germanus, habuit ab ecclesia accomodato" $" 80$.

29 kwietnia 1474 zapisano, iż Benedykt z Łopienna, czując zbliżającą się śmierć, przeznaczył Kościołowi gnieźnieńskiemu wszystkie swoje księgi. Niestety jednak nie podano dokładnego ich spisu: „Dnus Benedictus de Lopyenno testa-

\footnotetext{
76 Tamże, nr 1952.

77 Tamże, nr 2001.

78 Tamże, nr 2002.

79 Tamże, nr 2009.

${ }^{80}$ Tamże, nr 2045.
} 
mento et donacione inter vivos fieri consueta post suam mortem, quo ipsum contigit mori, omnes libros suos pro ecclesia Gnezn. legavit, ${ }^{81}$.

16 maja tegoż roku kanonicy Jan Nepos Brzostkowski i Benedykt Furman, obaj wieloletni prokuratorzy kapituły gnieźnieńskiej ${ }^{82}$, dzierżący w tym czasie pieczę nad wszystkimi kosztownościami kapitulnymi, prezentowali na specjalnym posiedzeniu zasoby skarbcowe (rodzaj kontroli mającej zapobiegać nadużyciom), w tym także drogocenne księgi liturgiczne oraz przywilej ze złotą pieczęcią: „Dni Nepos et Furman canonici, qui omnes res ecclesie in auro, argento, margaritis et aliis habuerunt in potestate, de eisdem dederunt racionem et dnis ibidem representaverunt, prout sequitur: (...) Item tria pontificalia. Item biblia in examento rubeo cum argenteis puclis deauratis. Item privilegium cum sigillo aureo. Item tria missalia: unum in rubeo examento, aliud in flaveo examento et aliud in rubea cuti cum puclis argenteis deauratis (...)" ${ }^{n 3}$.

20 kwietnia 1481 r. doktor Marcin z Niechanowa, przekazując Janowi Neposowi funkcję skarbnika, wraz z kluczami do skarbca zdawał mu cały jego zasób. W protokole „zdawczo-odbiorczym” znajdują się także informacje o drogocennych księgach, których - w porównaniu z rokiem 1474 - było znacznie mniej. Mowa jest tu tylko o trzech mszałach, nie było zaś już trzech pontyfikałów, Biblii i przywileju. Nie wiadomo - zaginęły one czy też aktualnie przechowywane były w innym miejscu:

„Repertorium rerum et reliquiarum (...), que vener. vir dnus Martinus decretorum doctor de Nyechanowo canonicus Gnezn. circa tradicionem clavium vener. dno Iohanni Nepoti canonico Gnezn. in thezauro demonstravit et tradidit cum clavibus (...). Item duo libri missalium cum pukle de argento deaurato: unum in rubeo coopertorio de examento et aliud in cute rubea. - Item tercium missale cum pukle argenteis in flaveo examento, aput vicecustodem demonstravit" ${ }^{\prime 4}$.

Dopiero 28 kwietnia 1481 pojawia się pierwsza informacja dotycząca polecenia zakupu książki na potrzeby kapituły za jej pieniądze. Zlecono wówczas Marcinowi Niechanowskiemu oraz oficjałowi, którym był podówczas Jakub Boksica, kupno książki zwanej Opat za pieniądze pochodzące z opłat wnoszonych przez nowo przyjętych członków zgromadzenia (cappalia). Niestety doszło tu do nadużycia - oficjał sprzeniewierzył pieniądze kapituły.

„Dni commiserunt dnis Martino Nyechanowsky et officiali, quod emant librum pro ecclesia dictum „Abbatem" pro pecuniis capparum"

Dzień później polecono kupno ksiąg Codicus oraz Volumen, na który to cel przeznaczono aż 8,5 florena (również z kapaliów). Do zapłacenia pozostawały jeszcze koszty oprawy:

„Dni... recognoverunt se emisse libros Codicum et librum dictum Volumen pro VIII $1 / 2$ flor., quos solvit dnus Nepos procurator capituli de pecuniis capparum

${ }^{81}$ Tamże, nr 2111.

${ }^{82}$ Zob. Gąsiorowski, Prokuratorzy, s. 453.

${ }^{83}$ Ulanowski 1894, nr 2112.

${ }^{84}$ Tamże, nr 2234.

${ }^{85}$ „Nieco późniejsza ręka dopisała na marginesie: quem dnus officialis emit pro se et non pro ecclesia suis pecuniis, Io. Przesyeka suscripsit”. Tamże, nr 2237. 
de mandato dnorum; restat introligatura solvenda dno officiali, qui ibidem eosdem libros recepit" $"$.

Wreszcie 6 marca 1482 r. za sześć florenów zakupiono księgę Digestum novum: „Dnus Iohannes Nepos, canonicus... et procurator capituli, de mandato dnorum archidiaconi, Nyechanowsky, Wladislai, Dambrovsky, officalis et Przesyeczsky solvit VI flor. pro libro dicto Novo digesto $" 87$.

26 kwietnia 1483 r. na kapitule generalnej kanonik Władysław zaprezentował książkę Summa aurea Henryka de Segusio (Hostiensis), którą niegdyś wypożyczył zmarły Piotr Pniewski: „Dnus Wladislaus canonicus presentavit dnis librum in pergameno summam Hostiensis, quem olim dnus Petrus Pnyewsky canonicus et officialis Gnezn. habuit de ecclesia Gnezn. in mutuum"\$8.

31 marca 1489 r. Albert Ksiąski wypożyczył od bibliotekarza gnieźnieńskiego Jakuba Boksicy kunsztowny rękopis Orygenesa (komentarz do Genesis): „Dnus Albertus Xanski scolasticus Crac. et Wlad. ac canonicus Gnezn. ecclesiarum stans recognovit se recepisse... a... dno Iacobo de Boxicze doctore canonico Gnezn. et alias de libraria de ipsius cura librum Origenis super Genesim in pergameno et in asseribus rubea cute subdutum..." ${ }^{89}$ Księga ta została zwrócona rok później, 21 kwietnia 1490: „Dnus doctor Boxicza recognovit, quod dnus Albertus Xanski librum ecclesie „Origenem super Genesim” per ipsum de anno preterito mutuatum eidem restituit" 90 .

22 października 1489 r. Jan Nepos Brzostkowski, kanonik gnieźnieński i poznański, podarował kościołowi gnieźnieńskiemu kielich srebrny z pateną oraz mszał pisany na pergaminie. Miała to być ofiara za dusze: własną oraz rodziców: „Dnus Iohannes de Brzosthkowo canonicus Gnezn. calicem satis notabilem argenteum et missale in pergameno ecclesie Gnezn. prefate pro remedio anime sue et suorum parentum dedit et irrevocabiliter donavit"91.

Podobną darowiznę uczynił 7 maja 1490 r. Marcin Niechanowski. Odnośna zapisek wymienia pięć dzieł w sześciu woluminach (zwyczajowo już z zakresu prawa i teologii). Co istotne - darczyńca zastrzegał sobie dożywotnie zachowanie ksiąg do własnego użytku, podczas gdy kielich trafić miał do kościoła bez żadnych warunków: „Dnus Martinus Nyechanowski doctor canonicus Gnezn. donavit ecclesie Gnezn. calicem argenteum cum patena deauratum preter pedem calicis et patenam. Item libros: Sextum in pergameno in asseribus rubea cuti obductum; item Fortalicium fidei; item Vitam Christi; item textum Sentenciarum cum conclusionibus ac titulis questionum s. Thome; item opera Iohannis Gerson cancellarii Parisiensis in II voluminibus: in uno volumine II partes et in secundo tercia, in asseribus rubea cuti apertis, in littera impressa, - quorum librorum reservavit sibi usum usque ad mortem, sed calicem simpliciter legavit pro ecclesia"92.

\footnotetext{
${ }^{86}$ Tamże, nr 2239.

${ }^{87}$ Tamże, nr 2241.

${ }^{88}$ Tamże, nr 2252.

${ }^{89}$ Tamże, nr 2292; Korytkowski IV, s. 374.

${ }^{90}$ Ulanowski 1894, nr 2313.

${ }^{91}$ Ulanowski 1894, nr 2302; Korytkowski I, s. 104.

${ }^{92}$ Ulanowski 1894, nr 2314; Korytkowski III, s. 95.
} 
W aktach kapitulnych pod datą 13 stycznia 1492 znalazła oddźwięk także znana sprawa wytłoczenia przez wędrownego drukarza z Frankonii Szwajpolta Fiola, popieranego przez bogatego kupca krakowskiego Jana Turzona, czterech dużych ksiąg liturgicznych dla Cerkwii prawosławnej. Księgi wydano w języku cerkiewnosłowiańskim, drukując je czcionką cyrylicką.

Przedsięwzięcie niestety upadło ze względu na zakaz cenzury kościelnej: „Ibidem ex parte honesti... Turzi civis Cracoviensis rogatum est, quatinus libros per eum impressos Ruthenicos et alios imprimendos sua Rma Ptas cum suis dnis admitteret ad publicandum, qui dnus Rmus Archiepus examinatis votis dnorum inhibuit et persuasit, ne publicarentur nec imprimerentur decreto" ${ }^{93}$.

Po śmierci arcybiskupa Zbigniewa Oleśnickiego (1492) kapituła zleciła Janowi Gosłubskiemu, aby odebrał z rąk spadkobierców prymasa przedmioty będące jej własnością. Gosłubski odzyskał i zwrócił kapitule drogocenny krzyż od ornatu, a także następujące księgi: Rubricam magistri Santconis (Sędziwoja z Czechła), Vitam sancte Kunegundis, Regestrum privilegiorum Ecclesie legatum oraz Acta Pontificia. Jak przypuszczał Jan Korytkowski „Vita sancte Kunegundis był to niezawodnie autograf Jana Długosza przypisany i ofiarowany przez niego prymasowi Jakubowi Sienieńskiemu, aby go pobudzić do gorliwego popierania kanonizacji tej świętej księżnej w Rzymie. Od Sienieńskiego dostał się widocznie rękopis do kapituły, która go wysoko ceniła, skoro go postawiła na czele wykazu przedmiotów przez proboszcza gnieźnieńskiego od spadkobierców arcybiskupa odebrać się mających. Niestety pamiątka ta po Długoszu drogocenna znikła z wielu innymi drogimi zabytkami z archiwum kapituły"94.

10 listopada 1497 r. doktor Paweł z Zalesia (prawdopodobnie ówczesnyy opiekun biblioteki) potwierdził przyjęcie ksiąg przekazanych kapitule w testamencie Jakuba Boksicy, kanonika gnieźnieńskiego, poznańskiego i krakowskiego, profesora teologii i medycyny w Akademii Krakowskiej, doktora teologii, obojga praw i filozofii. Wykonawcą jego ostatniej woli był kanonik gnieźnieński Klemens z Piotrkowa. Boksica legował swój księgozbiór profesorowi teologii i miał on już na zawsze pozostawać w jego domu. Miał z ksiąg korzystać wedle swej woli i dla własnych potrzeb, nie wolno mu było jednak ich zabierać czy przenosić. Cała kolekcja miała pozostawać nieuszczuplona i w niezmienionym kształcie służyć kolejnym wykładowcom. Zapis testamentowy obejmował 37 woluminów dzieł, w większości prawniczych: „Dnus de Zalessze, S. Theologie et decretorum doctor canonicus Gnezn., recognovit se recepisse et manualiter levasse infrascriptos libros a... dno Clemente de Pyotrkow, decretorum doctore archidiacono Calischiensi et canonico Gnezn., executore testamenti olim vener. Iacobi de Boxicze, S. Theologie Professoris et decretorum doctoris canonici Gnezn., quos libros prefatus olim Iacobus Boxicze legavit et donavit pro lectore theologie et inhabitatore

${ }^{93}$ Ulanowski 1894, nr 2329; Więcej na temat działalności Szwajpolta Fiola zob.: M. Błońska, Próba nowego spojrzenia na dzieje krakowskiej oficyny drukarskiej Szwajpolta Fiola (około 14831491), „Rocznik Biblioteki Narodowej”, 4 (1968) s. 51-62; Drukarze dawnej Polski od XV do XVIII wieku, t. 1, cz.1, Wrocław 1983, s. 25-39; P. Buchwald-Pelcowa, Cenzura w dawnej Polsce: między prasa drukarska a stosem, Warszawa 1997, s. 126-128.

${ }^{94}$ Korytkowski II, s. 104. 
domus Theologo deputate, ita, quod dnus Theologus tunc pro tempore existens debet eisdem libris uti ad voluntatem et pro necessitate sua, nec eosdem alienare libros a domo et a necessitate Theologi, sed iterum pro alio successore relinquere, qui sunt isti libri:

Repertorium legale in III voluminibus

Item Summa Astaxani

Franciscum de Zabarellis (s) super Clementinas

Item Panormitanum in IV voluminibus super Decretales

Item repertorium Panormitani

Item librum Institutorum

Item Alexandrum apostille super prima et secunda Inforciati

Item consilia Bartholi

Item summam Azonis

Item summam Hostiensis

Item Vocabularium iuris

Item consilia Angeli

Item Dominicum super Sexto in II voluminibus

Item Alexandrum super prima Digesti veteris

Item librum feudorum

Item Digestum vetus in II voluminibus

Item Digestum Inforciatum

Item Novellam Iohannis Andree in II voluminibus

Item Sententiarum in IV voluminibus s. Thome de Aquino

Item Scotum super Sententiarum in uno volumine

Item Decretum

Item Decretales

Item Sextum

Item Clementinas

Item Angelum super Institutionibus prima pars et secunda

Item repertorium super Innocencium in I volumine" 95 .

Jan Przesiecki, zmarły w 1498 roku kanonik gnieźnieński, prokurator kapituły w 1. 1481-1484 i 1486-1488, zapisał w swoim testamencie kapitule m.in. duos codices et viaticorum in pergameno ${ }^{96}$.

Kapituła gnieźnieńska dość szybko doceniła zalety wynalazku Jana Gutenberga. 26 kwietnia 1499 powierzyła kupcowi Piotrowi, mieszczaninowi poznańskiemu zadanie wydrukowania brewiarza gnieźnieńskiego. Najprawdopodobniej chodzi tu o Piotra z Lubeki, księgarza działającego w Poznaniu już przed r. 1477. W 1486 r. otworzył pierwszą księgarnię w Poznaniu, usytuowaną przy ul. Koziej. Sprze-

${ }^{95}$ Ulanowski 1894, nr 2498; Korytkowski I, s. 59; zob. też. W. Szelińska, Biblioteki profesorów Uniwersytetu Krakowskiego w XV i początkach XVI wieku, Wrocław-Warszawa-Kraków 1966, s. 142.

${ }^{96}$ Korytkowski III, s. 293-294. 
dawał on księgi religijne duchownym diecezji poznańskiej i gnieźnieńskiej, a od roku 1499 kapituły obu tych diecezji zlecały mu druk ksiąg kościelnych ${ }^{97}$ :

„Dni famoso Petro mercatori, de Poznania civi, viaticum rubrice ecclesie Gnezn. dederunt ad imprimendum, qui summisit se de bona littera facere impressam, et si infra hinc et festum s. Bartholomei prox. non prosequi negocium, extunc ipsum viaticum restituet et reponet ad ecclesiam Gnezn. Et quod non alius, nisi ipse Petrus, dictum viaticum ad imprimendum dabit, similiter competenti precio non gravando emptores, quod dni eidem constituet"98.

Rok później, 7 maja 1500 roku Piotr z Poznania dostarczył kapitule wydrukowane, nieoprawne brewiarze, których cenę $\mathrm{w}$ handlu detalicznym ustalono na 3 wiardunki: „Dni... breviaria in quinternis per Petrum de Poznania ad vendendum adducta taxaverunt per III fertones"

Zmarły w 1500 roku kantor gnieźnieński, archidiakon krakowski, doktor obojga praw, rektor Akademii Krakowskiej Jan Baruchowski w swoim testamencie zapisał kościołowi gnieźnieńskiemu mszał pisany na pergaminie ${ }^{100}$.

Ciekawym świadectwem dbałości kapituły o zasób biblioteczny jest zapiska z 22 października $1504 \mathrm{r}$. Na posiedzeniu generalnym zobowiązano wówczas wicedziekana do zwołania zebrania wikariuszy katedralnych i pouczenia ich, że ksiąg kościelnych nie wolno niszczyć dozwalając, by kapał na nie wosk z płonących świec. Widocznie więc wikariusze dopuszczali się tego typu niedbalstwa: „Dni... preceperunt vicedecano, ut vicariis iniungeret et preciperet, ne libros ecclesiasticos cera seu sepo spargerent et deturparent" ${ }^{101}$.

9 października 1506 r. trzech członków kapituły wypożyczyło książki z biblioteki gnieźnieńskiej. Doktor Paweł z Zalesia wziął De officiis misse: „Dnus Paulus Zalesszie, S. Th. Et decretorum doctor canonicus, recepit in mutuum librum Alberti, De officiis misse, de libris olim doctoris Boxicza"102.

Doktor Jan Grot pożyczył kilka dzieł treści teologicznej: „Item... dnus Iohannes Groth, decretorum doctor canonicus Gnezn., in mutuum recepit libros ecclesie donatos per olim doctorem Boxicza: Summam b. Thome: De Veritate, Contra gentiles, De potencia Dei; opuscula s. Thome; Albertum de laudibus Marie; Thomam super tercio; terciam partem s. Thome; preceptorium Speculi aurei; concordancias maiores" ${ }^{\prime 103}$.

${ }^{97}$ Privilegia typographica Polonorum: przywileje drukarskie 1493-1793, opr. M. Juda, Lublin 2010, nr 2; J. Ptaśnik, Cracovia impressorum XV et XVI saeculorum, Leopoli 1922, s. 88; A. Głowacka, Piotr z Lubeki, w: Wielkopolski Stownik Biograficzny (dalej: WSB), Warszawa-Poznań 1981, s. 570; W. Łoziński, Leopolitana, „Kwartalnik Historyczny”, 4 (1890) z. III, s. 452; J. Wiesiołowski, Ksiażka i biblioteki, w: Dzieje Poznania do roku 1793, t. 1, cz. 1, red. J. Topolski, Warszawa-Poznań 1988, s. 353; M.D. Łabędzka-Topolska, Księgarze, w: Dzieje Poznania, s. 538-539.

${ }^{98}$ Ulanowski 1894, nr 2524.

${ }^{99}$ Tamże, nr 2548.

${ }^{100}$ Korytkowski I, s. 35.

${ }^{101}$ Ulanowski 1894, $\mathrm{nr} 2631$.

102 Tamże, nr 2648.

${ }^{103}$ Tamże, nr 2649. 
Mamy tu informację, że książki te pochodziły z księgozbioru Jakuba Boksicy. Sprawa ta nie jest do końca jasna. W spisie książek przekazanych 10 listopada 1497 r. bibliotece kapitulnej na mocy testamentu Boksicy nie znajdujemy ani jednej z tu wymienionych. Kolekcja ta była dość jednorodna treściowo (dominowało w niej prawo), a ponadto przekazana została do użytku profesora teologii, donator zaś wykluczył możliwość wypożyczania. O ile zatem nie mamy tu do czynienia $\mathrm{z}$ pomyłką, wchodzić może $\mathrm{w}$ grę jedynie takie rozwiązanie, że Boksica drugą część swego księgozbioru, teologiczną, przekazał oddzielnym legatem (nieznanym nam dzisiaj) bibliotece kapituły, nie stawiając żadnych dodatkowych warunków i stąd, po włączeniu jej do zrębu głównego, udostępniana była ona na ogólnych zasadach.

Trzecim wreszcie wypożyczającym tego dnia był Maciej Kijowski, który pobrał drukowany egzemplarz Dekretu oraz księgę zwaną Faretram doctorum: „Item... dnus Mathias Kyowski canonicus Gnezn. recognovit se recepisse in mutuum ab ecclesia Decretum in littera impressa et librum «Faretram doctorum» apellatum $" 104$.

26 kwietnia 1507 r. kanclerz koronny Jan Łaski przekazał bibliotece katedralnej w Gnieźnie pergaminowy, oprawny egzemplarz Commune inclyti Polonie Regni privilegium, oraz inne nieoprawne egzemplarze pieczętne, tłoczone na pergaminie i papierze ${ }^{105}$ : „Nobilis Martinus Rambieski notarius R. Mtis nomine Rdi patris dni Iohannis Laski ecclesie Gnezn. et R. P. cancellarii donavit ecclesie statuta Polonie regni in pargameno impressa et bene ligata in uno volumine; item alia in quinternis pergamini et papiri sub sigillo R. Mtis"106.

Pod datą 17 stycznia 1510 zapisano, iż wykonawcy ostatniej woli zmarłego kanonika gnieźnieńskiego Jakuba Zaxińskiego albo Zakszyńskiego (z Zakszyna) przekazali w jego imieniu kapitule dwa kodeksy rękopiśmienne oraz oponę (Ibidem domini executores olim Jacobi Zaxinski canonici donaverunt ecclesie huic duos codices et oponkam $)^{107}$.

Oczywiście również w okresie późniejszym księgozbiór katedralny powiększany był darami i zapisami testamentowymi kanoników. I tak przykładowo, 9 lutego 1525 r. złożono kapitule tria volumina librorum satis notabilia - książki po Macieju Kijowskim ze Służewa (?) ${ }^{108}$. Stanisław Kilewski $(\dagger 1550)$ przekazał testamentem kapitule m.in. strophiola duo, librum biblie, missale Gnesnense Margarita adornatum, librum Poliantheam ${ }^{109}$. Trafiła do niego także kolekcja Szymona Borszyńskiego (†1590). Nie sposób jednak w jednym artykule prześledzić całości dziejów biblioteki instytucji istniejącej tysiąc lat. Nie jest to moim zadaniem. Na zakończenie jednak trzeba pokusić się o podsumowanie.

W początku omawianego tutaj okresu księgozbiór użytkowy kapituły gnieźnieńskiej nie był jeszcze raczej zbyt obfity i do końca lat 60 . XV wieku nie posia-

\footnotetext{
${ }^{104}$ Ulanowski 1894, nr 2650.

${ }^{105}$ Zob. Rył, Biblioteka Katedralna w Gnieźnie, s. 227.

${ }^{106}$ Ulanowski 1894, nr 2653.

${ }^{107}$ Korytkowski IV, s. 441.

${ }^{108}$ Korytkowski II, s. 258.

${ }^{109}$ Korytkowski II, s. 259.
} 
dał własnego lokum. Dopiero w połowie stulecia zauważono konieczność zorganizowania stałego pomieszczenia bibliotecznego, w którym umieszczono książki naukowe wykorzystywane przez kanoników i prałatów (zarówno uczniów, jak i profesorów).

Nie jest niestety możliwe jakiekolwiek uogólnienie ilościowe dotyczące omawianego okresu. Pierwszy zachowany katalog biblioteki kapitulnej w Gnieźnie pochodzi dopiero z 1608 roku, szacuje się jednak, że w początku XVI wieku biblioteka ta liczyła od 120 do 200 woluminów. Niewątpliwie był to zbiór wartościowy, intensywnie wykorzystywany nie tylko przez członków zgromadzenia, lecz także osoby spoza niego. Treściowo był on dość jednorodny i składał się z książek z zakresu prawa oraz teologii, choć należy się spodziewać, że wraz ze wzrostem dostępności książki, postępującej dzięki wynalazkowi druku wzrastało także jego zróżnicowanie tematyczne.

W przekazywanych bibliotece kapitulnej legatach reprezentowany jest cały podstawowy zasób prawa kanonicznego. Na początek więc Dekret Gracjana (zawierający przepisy dawnego prawa kanonicznego), przez Dekretały Grzegorza IX, Liber Sextus Bonifacego VIII aż do Klementyn ogłoszonych przez Jana XXII. Te cztery zbiory wyczerpywały cały materiał prawny przewidziany przy nauce prawa kanonicznego (ius canonicum). Oprócz tego mamy tu bogaty zestaw komentarzy do każdego z powyższych zbiorów. Ponadto reprezentowane jest tu także prawo rzymskie (ius civile) - Digesta i Nowele justyniańskie wraz z komentarzami. Przy tym, co ciekawe, o ile Digestum vetus oraz Infortiarum (czyli część „środkowa” między Digestum vetus a Digestum novum) zostały bibliotece darowane (zapis Jakuba Boksicy z 1497 r.), to musiała kapituła odczuwać brak właśnie Digestum novum, dlatego też poleciła je zakupić w 1482 roku.

Oddzielną kwestią był księgozbiór skarbcowy, składający się z bogato zdobionych, iluminowanych, oprawnych w srebrne i złocone oprawy ksiąg liturgicznych. W razie zagrożenia wojennego księgi te, wraz z innymi kosztownościami przewożone były do mocno ufortyfikowanego zamku arcybiskupiego w Uniejowie (skarbiec gnieźnieński niestety nie gwarantował bezpieczeństwa w razie napaści zbrojnej). Istniały także wreszcie oddzielne księgozbiory, znacznie mniejsze i mało znane: wikariuszy wieczystych katedry oraz penitencjarzy katedralnych. Ponadto własną biblioteczkę posiadał dom profesora teologii. Te zbiory w pewien sposób dopełniały bibliotekę kapitulną.

Biblioteka powstająca z darów i zapisów testamentowych nie mogła uniknąć jednej niedogodności, immanentnie zawartej w takim modelu gromadzenia: narastania dubletów. Nie mamy informacji, w jaki sposób postępowano z kolejnymi egzemplarzami tego samego dzieła. Niektóre z nich z pewnością przekazywano na użytek przykatedralnej szkoły (była to zwykła praktyka). Z drugiej strony 
z pewnością posiadanie większej ilości dzieł najbardziej poczytnych było zjawiskiem pożądanym.

\section{Poznań}

W 1431 roku rozpoczęła się trwająca wiele lat przebudowa katedry poznańskiej. 5 czerwca 1435 r. kapituła wyznaczyła Macieja z Tarnowa, kanonika poznańskiego, opiekunem budynku kościoła katedralnego. Jego głównym zadaniem miało być zaś doprowadzenie do końca prac nad pomieszczeniem biblioteki. Pomocą Maciejowi służyć miał Jan Furman ${ }^{110}$. Z zapiski tej wnosić by można, iż kapituła poznańska dość wcześnie zatroszczyła się o oddzielne pomieszczenie na potrzeby biblioteki i posiadała je kilkadziesiąt lat wcześniej niż kapituła gnieźnieńska. Uchwały tej jednak chyba nie wykonano, ponieważ 1 lipca 1458 roku na posiedzeniu generalnym kapituła postanowiła zmienić kaplicę św. Zofii na kapitularz, a dotychczasową kaplicę kapitularza przeznaczyć na bibliotekę ${ }^{111}$. Także i tego postanowienia nie wykonano w całości. Miejscem zgromadzeń kapituły pozostała nadal kaplica Św. Ducha i świętych Apostołów. Natomiast bibliotekę przeniesiono jeszcze przed 1472 r. do wieży południowej, do pomieszczenia położonego nad izbą dzwonników za kaplicą św. Apolonii. Tutaj mieściła się ona aż do roku 1781.

Nieliczne najcenniejsze księgi przechowywane były w skarbcu katedralnym. B. Ulanowski opublikował dwa spisy zasobów skarbcowych katedry poznańskiej $^{112}$. W pierwszym z nich, pochodzącym z 12 lipca 1525, czytamy m.in.:

„Item aurum in lamine depositum ex libro Evangeliorum in carta papiri involutum

Item liber biblie olim Ade decani axamento nigro et clausuris argenti reformatus Item Speculum Durandi”.

W spisie z 9 sierpnia 1530 roku nie znalazło się już dzieło Wilhelma Duranda. Nie wiemy, czy Ewangelie, z których usunięto płatki złota, znajdowały się w posiadaniu kapituły poznańskiej i - jeśli tak - czy były również przechowywane w skarbcu. Nie wiemy także, z jakiego powodu trafił tam Durandus. Być może stało się tak przypadkowo i ponieważ nie była to w rzeczywistości drogocenna księga, przeniesiono ją po dokonaniu pierwszego spisu do biblioteki. Biblia oprawiona w czarny aksamit i ze srebrnymi zamknięciami pochodziła prawdopo-

110 „Item ibidem honor. dnum Mathiam de Tarnowo canon. Poznan. in mgrum fabrice deputaverunt, qui dnus Mathias primo et principaliter librariam in finem bonum terminare debet, decernentes, quod vener. dnus Clemens scolasticus dabit X marcas aut quantum habere poterit pro fabrica ecclesie ac dicta libraria finienda pro hac vice, quam librariam reparavit cum dno Johanne Furman". Ulanowski 1894, nr 175.

${ }^{111}$ „Item concluserunt, quod capella capitularis aptetur pro loco librarie et capella altaris s. Zophie pro loco capitulai apretur". Ulanowski 1894, nr 497.

${ }_{112}$ Akta kapitut z wieku XVI wybrane. Tom I. Część I. Akta kapitut poznańskiej i włoctawskiej (1519-1578), wyd. B. Ulanowski, Kraków 1908 (dalej cyt. jako Ulanowski 1908), s. 3; 17. 
dobnie z daru Adama z Dąbrowy, dziekana poznańskiego ${ }^{113}$, który w roku 1491 „darował kościołowi poznańskiemu Biblię pisaną na pergaminie”"14.

Zarząd biblioteki katedralnej, która stanowiła własność kapituły, spoczywał nominalnie w ręku kanclerza kapituły (w katedrze gnieźnieńskiej kierowanie biblioteką należało zawsze do prokuratora). Kapituła gremialnie czuwała nad całością księgozbioru, sprawdzała komisyjnie stan biblioteki i wypożyczenia książkowe, opłacała oprawę kodeksów. Wielokrotnie wyznaczano prałatów i kanoników, którzy mieli przeprowadzić rewizję biblioteki lub też na nowo ją zinwentaryzować. Natomiast faktycznie bezpośrednią opiekę nad nią sprawował w XV w. notariusz lub jeden z wikariuszy wieczystych. W roku 1449 klucze do biblioteki posiadał proboszcz katedralny ${ }^{115}$. 4 lipca 1453 r. opiekę nad księgozbiorem powierzono oficjałowi Jakubowi Wygonowskiemu młodszemu ${ }^{116}$ oraz kanonikom Janowi Twardowskiemu ${ }^{117}$ i Rogalińskiemu (Item dnos officialem, Twardowski et Rogalinski ad vivendum, numerandum et conscribendum libros deputaverunt ${ }^{118}$ ). Twardowski pełnił tę funkcję jeszcze w r. 1457, po nim natomiast w latach 14581464 opiekunem biblioteki był wikariusz Mikołaj Godziemba. Wyznaczony został na tę funkcję 4 lipca 1458, a objąć ją miał po przeprowadzeniu rewizji inwentarza bibliotecznego przez prałatów: „Dni custos, Pczewensis, cantor et Mathias deputati sunt ad audiendum racionem contribucionis per dnum Twardowski collecte, similiter ad revidendum inventarium librarie, cuius custodiam commiserunt dno Nicolao Godzambe cum clavibus"119. Dwie dalsze wzmianki, z 23 listopada 1462 i 28 grudnia 1464 poświadczają, iż za opiekę nad księgami Godziemba otrzymywał zapłatę w wysokości jednej grzywny rocznie ${ }^{120}$. W latach 1471-1482 opiekę nad księgozbiorem sprawował notariusz Piotr Kobylnicki ${ }^{121}$.

${ }^{113}$ Kanonik poznański od 1452 r., dziekan od 1479 r. aż do śmierci w 1494 r. P. Dembiński, Udziat prałatów i kanoników w posiedzeniach poznańskiej kapituly katedralnej za pontyfikatu biskupa Uriela z Górki (1479-1498), „Roczniki Historyczne”, 66 (2000) s. 186.

${ }^{114}$ Korytkowski I, s. 194.

${ }^{115}$ Ulanowski 1894, nr 363.

116 Jakub syn Piotra (Jacobus Petri), bratanek Jakuba starszego, późniejszy doktor dekretów uniwersytetu w Rzymie. Zob. H. Barycz, Polacy na studiach w Rzymie w epoce Odrodzenia (14401600), Kraków 1938, s. 39; J. Nowacki, Zapiski historyczne z lat 1410-1530 (z ksiag Archiwum Archidiecezjalnego w Poznanaiu), „Studia Źródłoznawcze”, 3 (1958) s. 156, przypis 12 i 13. Co ciekawe, według Barycza i Nowackiego, Jakub został kanonikiem poznańskim właśnie w tym roku, tak więc owe księgi prawnicze wypożyczył wkrótce po powrocie do kraju i swojej instalacji w kapitule. Natomiast według P. Dembińskiego (Wykształcenie prałatów, s. 53) Jakub w tym właśnie roku uzyskał doktorat w Rzymie, natomiast archidiakonem pszczewskim był już od 1449 r. (następnie zaś wikariuszem generalnym w 1. 1453-1457 oraz scholastykiem w 1. 1457-1484).

${ }^{117}$ Kanonik katedralny, oficjał warszawski w 1. 1446-1447, zmarł 1467 r. Zob. J. Nowacki, Zapiski historyczne z lat 1410-1530, s. 157.

${ }^{118}$ Ulanowski 1894, $\mathrm{nr} 417$.

${ }^{119}$ Ulanowski 1894, nr 498.

120 „Ibidem dno Nicolao Godzyamba vicedecano Pozn. racione servicium, que exhibet circa librariam, unam marcam dari mandaverunt”. Ulanowski 1894, nr 563; „Ibidem dno Nicolao Godzambe unam marcam racione custodie librarie dari mandarunt". Ulanowski 1894, nr 585.

${ }^{121}$ Ulanowski 1894, nr 706. 
Prałaci i kanonicy w XV i pocz. XVI wieku często korzystali z biblioteki, wypożyczając z niej - za zgodą kapituły - potrzebne im kodeksy. By jednak wypożyczyć książkę, potrzebne było poręczenie innego członka kapituły. I tak na przykład 19 marca 1444 roku prepozyt ${ }^{122}$, za poręczeniem kantora i kanonika Jakuba Wygonowskiego, wypożyczył Biblię należącą niegdyś do Piotra Wysza, zmarłego w 1414 roku biskupa krakowskiego i poznańskiego ${ }^{123}$. Dwóm innym kanonikom potrzebne były dzieła prawnicze: Wygonowski wypożyczył Dekret Gracjana, Dekretały Grzegorza IX oraz Liber Sextus (za poręczeniem kantora i prepozyta), kanonik Maciej zaś Liber Sextus (za poręczeniem kanonika Zbyluta). Księgi miały zostać zwrócone na najbliższym posiedzeniu generalnym kapituły. „De libris ecclesie - Die Iovis... dni prepositus, cantor, cancellarius, Srzemensis, Varschoviensis archidiaconi, Vigonowsky, Lanthman, Jacobus [de] Grandi, Iohannes de Nyewesch, Twardowsky, Mathias, Viscotha, Sbilutus, Sandivogius... mandaverunt mutuare preposito bibliam olim dni Wysch, pro quo cantor et Vigonowsky fideiusserunt. Item dno Vigonowsky Decretum, Decretales et Sextum, pro quo cantor et prepositus fideiusserunt. Item Mathie Sextum, pro quo Sbilutus fideiussit, quos libros reposituri sunt in capitulo generali proximo" 124 .

Cztery lata później, 5 czerwca 1448 roku, wicekustosz Michał zaprezentował kapitule 22 woluminy, w tym także nieznane dzieło pisane na pergaminie, pochodzące z daru biskupa Stanisława Ciołka ${ }^{125}$ i przechowywane w skarbcu, z którego pozwolono mu nadal korzystać, natomiast kanonik Klemens wypożyczył dzieło medyczne: „Item dnus Michael vicecustos presentavit viginti duo volumina inclusive cum magno sexterno in pergameno de libris olim dni Czolkonis, quos vice versa recepit ad thezaurum, et dnus Clemens recepit librum de medicinis sub caucione restitutionis" 126 .

W następnym roku, 10 lutego 1449, oficjał Mikołaj z Kościana ${ }^{127}$ wypożyczył Dekret (wartość księgi oceniono na 40 florenów), Speculum iudiciale Wilhelma Duranda, tzw. Speculator (również 40 florenów) oraz dawną biblię, współopra-

${ }^{122}$ Wiesiołowski, Społeczeństwo a książka, s. 71, identyfikuje tego proboszcza katedralnego z magistrem Wyszotą z Górki, choć J. Krzyżaniakowa, Urzędnicy kancelarii królewskich w wielkopolskich kapitułach katedralnych w XV w. w: Droga historii, red. P. Dymmel, K. Skupieński, B. Trelińska, Lublin 2001, s. 247, stwierdza, że był on prepozytem jedynie do roku 1442. Na temat wykształcenia Wyszoty z Górki zob. Dembiński, Wyksztatcenie prałatów, s. 38-39.

123 Zob. W. Seńko, Piotr Wysz z Radolina (*ok. 1354 - †1414) i jego „Speculum aureum”, Warszawa 1996. Tam też zestawienie bibliograficzne. Zob. też biogram pióra Jana Długosza w: Katalogi biskupów poznańskich, opr. J. Wiesiołowski, Poznań 2004, s. 30-32. Biogram autorstwa Franciszka Rzepnickiego, tamże, s. 116-118.

${ }^{124}$ Ulanowski 1894, nr 287.

${ }^{125}$ Najnowsze opracowanie dotyczące tej postaci: Z. Kowalska, Stanisław Ciolek (+1437), podkanclerzy królewski, biskup poznański, poeta dworski, Kraków 1993. Nie wiemy jednak praktycznie nic na temat księgozbioru podkanclerzego i biskupa. Zob. też biogram pióra Jana Długosza w: $K a$ talogi biskupów poznańskich, s. 33-34. Biogram autorstwa Franciszka Rzepnickiego tamże, s. 120.

${ }^{126}$ Ulanowski 1894, nr 356.

${ }^{127}$ Mikołaj Hesken z Kościana, zmarły w 1485 roku doktor dekretów. W latach 1449-1450 był wikariuszem generalnym i oficjałem poznańskim (Nowacki, Zapiski historyczne, s. 156, przypis 10), zaś kanonikiem poznańskim został dopiero w roku 1454 (WSB, s. 252-253). Zob. też. Dembiń- 
wioną z jakąś kroniką. Poręczycielami byli kustosz oraz kanonik Sędziwój (Sobocki? ${ }^{128}$ : „Vener. Dni prepositus, archidiaconus, Praszmowsky, Hector, Vigonowsky, Twardowsky, Miroslaus, Mathias, Sbiluthus, Viscota, Sandivogius, Czaczsky, Chibsky, Rogalinsky accomodaverunt vener. dno Nicolao de Costen officiali et vicario in Spiritualibus Decretum in valore XL flor., Speculatorem in valore XL flor. et bibliam veterem cum cronicis in uno volumine, pro quo dni custos et Sandivogius fideiusserunt. Item ibidem claves a libraria tradiderunt dno prepositi ad prox. capitulum generale"129.

4 lipca 1453 roku cztery książki teologiczne wypożyczył oficjał Jakub Wygonowski: „Item libros Exameron, bibliam, Moralia et Dionisium de celesti ierarchia accomodaverunt dno officiali"”30.

Z 3 lipca 1472 roku mamy zapiski o kolejnych zwrotach i wypożyczeniach: „Libri ecclesie - Dnus Uriel prepositus Poznan. reposuit decretales, et iterum recepit; item dnus decanus Poznan. reposuit bibliam in axamento rubeo et iterum recepit; item dnus Schkudla reposuit decretum et decretales et iterum recepit; item dnus doctor de Costen reposuit decretum maius, item librum sextum, item Franciscum de Zabarellis super Clementinas, item librum in pargameno de veteri scriptura, in quo continentur epistole b. Ieronimi et beatus Ieronimus super minores prophetas, et iterum recepit. Item dnus Pleschewsky reposuit librum Vincencii in Speculo et non recepit"131.

Mamy tu kolejną wzmiankę na temat wypożyczania książek przez Mikołaja z Kościana, którego nadal interesowały głównie dzieła prawnicze, wypożyczył jednak także jedną książkę teologiczną. Zainteresowania prawnicze przejawiał również Uriel z Górki, ówcześnie prepozyt (proboszcz katedralny), a później biskup poznański (1479-1498), kanclerz Królestwa (1473-1479), wykształcony w Krakowie, Niemczech i Bolonii. Decretum i Decretales wypożyczył Mikołaj ze Szkudły ${ }^{132}$, który testamentem legował swój księgozbiór kapitule (zob. niżej; Mikołaj był także autorem objaśnień do tychże, wypożyczonych z biblioteki Dekretałów, zob. niżej zapiskę dotyczącą depozytu Jana Górskiego). Wreszcie dziekan Adam z Dąbrowy wypożyczył Biblię oprawioną w czerwony aksamit, zaś kanonik Stanisław Pleszewski Speculum Wincentego z Beauvais.

Księgi wypożyczane ze zbiorów kapituły musiały być w określonym terminie zwrócone bądź też prezentowane zgromadzeniu kanoników, jeśli wypożyczający chciał nadal zatrzymać książkę. Ciekawa jest ostatnia wzmianka, że kanonik Pleszewski nie otrzymał z powrotem wypożyczonej książki. Nie wiemy, czy nie była mu już dłużej potrzebna, czy też naruszone zostały jakieś reguły (przekroczony

ski, Wykształcenie prałatów, s. 58; 63. Zob. też G. Piechota, Mikołaj z Kościana i jego księgozbiór, „Folia Bibliologica”, 48/49 (2006/2007) s. 25-40.

${ }^{128}$ Nowacki, Zapiski historyczne, s. 158, przypis 24.

${ }^{129}$ Ulanowski 1894, nr 363.

${ }^{130}$ Ulanowski 1894, nr 417.

${ }^{131}$ Ulanowski 1894, nr 622.

132 Archidiakon śremski (1459-1500), wykształcony we Włoszech doktor dekretów, notariusz publiczny, wikariusz generalny i oficjał generalny poznański w 1. 1479-1484 i 1487-1499. Dembiński, Wykształcenie pratatów, s. 53, 59, 63. 
termin zwrotu, księga została podniszczona, kanonik nie dbał o nią należycie), czy też może zapotrzebowanie na nią zgłosił ktoś inny i w związku z tym kapituła nie zgodziła się na przedłużenie wypożyczenia.

Z kapitulnej książnicy korzystały niekiedy także osoby spoza kleru katedralnego. 11 września 1449 roku kasztelanowi poznańskiemu Dobrogostowi Świdwie z Szamotuł ${ }^{133}$ wypożyczono Dekretały, za które zapłacił on kaucję „,wielkiej wartości”: „Ibidem decreverunt, ut accomodaverunt Decretales magnifico dno Dobrogostio castellano Poznan. daturo pro eis caucionem cum personis capitularibus maioris valore" 134 .

Nowo założonemu klasztorowi bernardynów w Poznaniu 18 października 1457 r. wypożyczono Sentencje Piotra Lombarda, Historia scholastica Piotra Komestora, Cur Deus homo św. Anzelma oraz konkordancje ewangeliczne: „Item ibidem dnus Iohannes Twardowski de consensu dnorum suprascriptorum accomodavit fratribus Bernardinis libros videlicet: Sentenciarum, Scolasticam hystoriam, Cur deus homo et Concordancias Ewangelistarum"135.

Jak dowiadujemy się z zapiski z 3 stycznia 1482 roku, kapitule gnieźnieńskiej wypożyczono Digesta. Opiekun biblioteki Piotr Kobylnicki przekazał tę księgę Jakubowi Jabłonowskiemu, który wraz z dziekanem poznańskim, Adamem z Dąbrowy, poręczył, że zostanie ona zwrócona w czasie targu na początku Wielkiego Postu. Jak się jednak okazało, w wyznaczonym terminie zwrócono tylko dwa $\mathrm{z}$ trzech tomó $\mathrm{w}^{136} .27$ woluminów z podstawowymi tekstami prawa rzymskiego i kanonicznego, kazaniami i komentarzami wypożyczył w 1457 r. z biblioteki katedralnej poznańskiej doktor Stanisław Mysznar, prepozyt szamotulski, tworząc bibliotekę w Szamotułach. W mieście tym Szamotulscy utworzyli w 1423 r. prepozyturę z ośmioma mansjonarzami i dwoma kaznodziejami. Wypożyczano również książki do użytku profesorów Akademii Lubrańskiego. Zużyte księgi oddawane były natomiast do użytku szkoły katedralnej. Przypadek taki miał miejsce 20 listopada 1434 roku, kiedy to na prośbę scholastyka Mikołaja przekazano jej stary graduał ${ }^{137}$. Jak konstatuje Jacek Wiesiołowski, ,spora ilość wypożyczeń osobom spoza kapituły, tak księżom, jak klasztorom, a nawet świeckim dostojnikom wskazuje, iż była to biblioteka otwarta i silnie oddziałująca na środowisko"138.

Ponieważ księgi były dobrem drogim i rzadkim, często traktowano je jak walutę czy też lokatę kapitału. 1 lipca 1450 r., na posiedzeniu generalnym kapituły, postanowiono właśnie książkami (15 woluminów) spłacić długi zmarłego biskupa

${ }^{133}$ A. Gąsiorowski, Urzędnicy wielkopolscy 1385-1500. Spisy, Poznań 1968, s. 65.

${ }^{134}$ Ulanowski 1894, nr 374.

${ }^{135}$ Ulanowski 1894, nr 477.

136 „Item mandaverunt mutuare libros digestorum capitulo Gnezn., quos a me in tribus voluminibus Petro Cobylnyczsky protunc custode librorum dnus Iablowsky Iacobus recepit, et pro ipsis cum dno decano Poznan. cavit hinc et nundinas Poznan. in inicio quadragesime restituendos; iam duos restituit, tercius ibi habetur". Ulanowski 1894, nr 706.

137 „Item ibidem graduale antiquum, quod est ecclesie Pozn., ad petitionem vener. dni Nicolai scolastici Pozn. ad usu scole Summi Pozn. concesserunt”. Ulanowski 1894, nr 162.

${ }_{138}$ J. Wiesiołowski, Średniowieczne biblioteki wielkopolskie, w: Średniowieczna książka rękopiśmienna jako dzieło sztuki, Gniezno 1993, s. 12. 
Stanisława Ciołka: „Presentibus dnis Twardowsky, Miroslao canonicis, Naczkone in Wissoczko, Iacobo in Bythin plebanis, Mathia et Nicolao campanatoribus, nobilis Wyschota de Bloszegewo cum fratribus et amicis receperunt de manibus dni Michaelis vicecustodis et de thezauraria ecclesie XV volumina per dnum Predvogium prepositum Poznaniensem reposita, olim dni Stanislai Czolek Epi Pozn. Executorem, ad racionem debiti, in quo ipsis prefatus dnus Epus tenebatur, et super quo dnis capitulo Poznan. in iudicio seculari moverant accionem, cui renunciaverunt et cesserunt, ipsumque capitulum ecclesie Poznan. in totum quo ad huiusmodi debitum quittaverunt et absolverunt, promittentes ulterius et amodo non inquietare neque impedire" 139 .

Dwa dni później oddano w zastaw, za 20 grzywien w półgroszkach, dziekanowi włocławskiemu Janowi, Biblię biskupa Ciołka, zobowiązując się jednocześnie do odkupienia jej w najbliższy dzień św. Tomasza Apostoła. Gdyby kapitule nie udało się dokonać wykupu, Jan mógł zatrzymać księgę: „Item bibliam olim dni Czolconis Epi Poznan. obligaverunt dno Iohanni decano Wladisl. in XX marcis mediorum gr. reempturi eandem ad festum $b$. Thome apostoli prox., alias si non fecerint, extunc licebit dicto dno decano eandem bibliam, si volverit, in tanta summa XX marcarum obligare, ubi poterit et velit, ad quod dni consenserunt et ad interesse pro dampnis et impedimentis se submiserunt" ${ }^{\prime 40}$.

Osiem lat później, 11 lipca 1458 roku, również na posiedzeniu generalnym kapituły, postanowiono sprzedać jedną z ksiąg podarowanych kapitule przez Jaśka z Czechła ${ }^{141}$ (Hungwicjusza, czyli być może chodzi tu o sumę Huguciusa z Pizy). Nabywcą był Mikołaj z Kościana, a cenę ustalono na dwie kopy (120) groszy. Uzyskanymi w ten sposób pieniędzmi miano spłacić w większości dług wobec Fawkona, któremu kapituła winna była trzy grzywny (144 grosze): „Vener. patres et dni librum Hungwicium per dnum Iaskonem pro ecclesia Poznan. legatum vendiderunt mgro Nicolao de Costen pro duabus sexagenis, quas dni dederunt provido Fawkoni ad racionem trium marcarum, in quibus sibi tenebatur"142.

W tym kontekście nie może dziwić wzmianka z roku 1448, kiedy to jednemu z uczniów szkoły katedralnej poznańskiej skradziono „kodeks z utworami szkolnymi, zawierający m.in. regule de medicinis. $\mathrm{W}$ rękopisie powstałym $\mathrm{w}$ tejże szkole w drugiej połowie XV w. jej uczeń Wojciech z Pniew wpisał list magistra Arnolda de Villa Nova do arcybiskupa Canterbury (BJ 2458, s. 204-206), po nim zaś kilka prognostyków pogody"143.

Przyjrzyjmy się teraz $\mathrm{w}$ jaki sposób narastał księgozbiór katedralny. Z wieków średnich nie przetrwały niestety żadne inwentarze biblioteki poznańskiej. Najstarszy zachowany pochodzi dopiero z 1683 roku. Według inwentarza z roku 1781 biblioteka kapitulno-katedralna liczyła (oprócz przechowywanych w skarb-

${ }^{139}$ Ulanowski 1894, nr 385.

${ }^{140}$ Ulanowski 1894, $\mathrm{nr} 386$.

${ }^{141}$ Jaśko z Czechła, zmarł 1444; posiadał on stosunkowo zasobną bibliotekę o profilu głównie prawniczym, z której drobne legaty testamentowe przekazał m.in. kapitule poznańskiej.

${ }^{142}$ Ulanowski 1894, nr 501.

${ }^{143}$ Por. J.A. Spież, Moralitety mistrza Mikołaja Olocha z Szamotut, „Studia Źródłoznawcze”, 13 (1968) s. 75. 
cu cymeliów i ksiąg liturgicznych chóru i zakrystii) 832 woluminy, w tym 97 rękopisów ${ }^{144}$. Jak pisze Jacek Wiesiołowski, „charakterystycznym był - podobnie jak dla Gniezna - spory udział prawa kościelnego z tekstami i zbiorami komentarzy prawniczych. Słabo reprezentowane były teksty z teologii i filozofii uniwersyteckiej. Do 1520 r. wiadomo z przypadkowych wzmianek o ponad 300 kodeksach, całość księgozbioru zapewne dochodziła do tysiąca książek" 145 . Z owych przypadkowych wzmianek najistotniejsze są zapisy dużych legatów książkowych, pochodzące z pierwszej ćwierci XVI w. - Mikołaja ze Szkudły, Jana Łukowskiego oraz biskupa Jana Lubrańskiego.

13 sierpnia 1500 r. przyjęto księgi zapisane kapitule przez Mikołaja ze Szkudły, prawnika, archidiakona śremskiego. Mikołaj ,zgromadził znaczny księgozbiór, przekraczający setkę tomów, przede wszystkim dzieła prawnicze, zarówno zbiory prawa kanonicznego, jak komentarze czołowych włoskich specjalistów od prawa kanonicznego i rzymskiego. Mniej wartościowa była teologiczna część księgozbioru, zawierająca popularną literaturę teologiczną i łatwiejsze teksty klasyków teologii. Biblioteka składała się prawie wyłącznie z druków. Najważniejsza jej część - 62 inkunabuły - została przez Mikołaja ofiarowana bibliotece katedralnej w Poznaniu. Drobniejsze dary książkowe otrzymali benedyktyni lubińscy, dominikanie poznańscy, bratanek Paweł ze Szkudły, doktor teologii, kanonik poznański Jan Górski i prawdopodobnie inne osoby. Biblioteka Mikołaja, zwłaszcza w swej części prawniczej, podtrzymywała tradycję uczonych bibliotek późnośredniowiecznych kanoników wielkopolskich"146. „Mikołaj preferował dzieła prawnicze, jako wychowanek włoskich prawników gromadził głównie komentarze Jana Andrzejowego, Zabarelli, Oldrada, Saxoferrato, Butrio, Baldiego, Geminiano, Trano, Panormitana (...) Miał też popularne zbiory kazań Leonarda z Utino, Socci ${ }^{147}$, Wincentego z Ferrary ${ }^{148}$, popularne kompendia i podręczniki teologiczne, konkordancje Biblii - typowe dla kręgu altarystów - oraz trochę poważniejszej literatury teologicznej: Augustyna, Bernarda z Clairvaux, Antonina z Florencji”"149. Dodać do tego jeszcze można, że Mikołaj posiadał także ,wydany drukiem po raz pierwszy w r. 1486, (...) bez wątpienia najważniejszy, a jednocześnie najbardziej złowrogi traktat napisany przeciwko czarownicom w dziejach ludzkości" ${ }^{150}$, czyli osławiony Młot na czarownice dominikanów Jakuba Sprengera i Heinricha Krammera. Ponadto w jego księgozbiorze znalazły się: jakiś leksykon obojga praw oraz formularz notarialny.

Jest to chronologicznie pierwszy duży legat zapisany bibliotece kapitulnej, o którym wiadomość odnajdujemy w księdze metryki: „Die Iovis XIII-ma m.

${ }^{144}$ Nowacki, Kościół katedralny, s. 313, 563-566.

${ }^{145}$ Wiesiołowski, Średniowieczne biblioteki, s. 14.

${ }_{146}$ J. Wiesiołowski, Mikołaj ze Szkudly, WSB, s. 481.

${ }^{147}$ Cysters Konrad von Brundelsheim, zwany Frater Soccus, jeden z najpopularniejszych kaznodziejów średniowiecza.

${ }^{148}$ Właściwie Jana z Ferrary (practica Iohannis de Ferrariis), pomieszanego tutaj z Wincentym Ferrerem.

${ }^{149}$ Wiesiołowski, Społeczeństwo a książka, s. 70.

${ }^{150}$ R.H. Robbins, Encyklopedia czarów i demonologii, Warszawa 1998, s. 198. 
Augusti venerandus olim dnus Nicolaus de Scudla decretorum doctor egregius et practicus peritus archidiaconus Srzemensis in ecclesia Poznan. sacramentis Eucaristie et Unctionis extreme procuratus vitam suam laudabiliter hora decima octava in domo sua penes curiam episcopalem ad ipsam ecclesiam Pozn. sita finivit et LXII volumina librorum infrascriptorum testamentaliter dicte ecclesie Pozn. donavit ac legavit A.D. MD:

Item fasciculus temporum cum consiliis Abbatis

Item glosa super Clementinas Siculi abbatis

Item liber quartus Francisci de Zabarelli super quarto Decretalium

Item Decretalia in pergameno scripta

Item consilia Oldradi

Item Digestum vetus

Item Codex seu Autentica

Item Digestum Novum

Item casus Iohannis Durandi super corpus iuris civilis

Item decisiones rote

Item Liber VItus in pergameno scriptus Siculi

Item liber de sponsalibus et matrimoniis super quartum et quintum abbatis

Item super tertium eiusdem abbatis

Item lectura dni Bartholomei de Saxoferrato super Autenticis

Item Abbas super primum Decretalium

Item Abbas super secundum Decretalium

Item Abbas super tertium Decretalium

Item Novella Iohannis Andree super Sextum di

Item Speculum Gwillelmi Durand cum addicionibus Iohannis Andree et Bal-

Item pars secunda eiusdem Gwillelmi

Item pars tertia eiusdem Gwillelmi

Item liber Codicum cum apparatu

Item Franciscus de Zabarellis super Clementinas

Item interpretatio Anthonii de Butrio a titulo de translatione prelatorum

Item Novella Iohannis Andree super primo Decretalium

Item super quinto Decretalium eiusdem

Item repertorium utriusque iuris Iohannis Bertachii de Firmo

Item lectura Francisci de Zabarellis super Clementinas in papiro scripta

Item summa Hostiensis

Item prima pars repertorii utriusque iuris Iohannis Berthachy de Firmo

Item secunda pars eiusdem

Item Decretum

Item repertorium Calderini

Item repertorium Nicolai de Milis

Item Speculum aureum decem preceptorum fratris Henrici ordinis Minorum

Item Henricus de Piro super Institutis

Item nove decisiones rote 
Item repertorium Baldi alias Innocentianus

Item questiones Bartholomei Brixiensis in pargameno scripte

Item interpretationes Dominici de Geminiano super Sextum

Item prima pars summe Anthonii

Item secunda pars eiusdem Anthonii

Item tertia pars eiusdem

Item quarta pars eiusdem

Item vita Christi

Item sermones Socci de tempore

Item summa angelica

Item summa Goffredi in pargameno

Item Lumen anime

Item repetitio Baptiste de s. Blasio

Item prima pars lecture Dominici de Geminiano super Sextum

Item Infortiatum legum

Item Decretales cum apparatu

Item margaritha Decreti

Item concordantie Ewangelistarum et Biblie

Item sermones Socci de Sanctis

Item Catholicon

Item Omeliarius doctorum

Item practica Iohannis de Ferrariis

Item vocabularius utriusque iuris

Item formularius instrumentorum

Item maleus maleficarum

Summa eorundem voluminum LXII ${ }^{151}$.

Na posiedzeniu generalnym kapituły 28 czerwca 1515 roku przyjęto legat pozostawiony przez Jana Łukowskiego h. Dryja ${ }^{152}$, zmarłego w poprzednim roku. Jak pisze Jacek Wiesiołowski, Łukowski ,pozostawił bogatą bibliotekę, liczącą ok. 110 dzieł, złożoną głównie z druków, którą przekazał bibliotece kapituły poznańskiej. Był to księgozbiór przede wszystkim prawniczy - zbiory praw, komentarze autorów włoskich, kompendia, nieco książek teologicznych - komentarze biblijne, ojcowie i doktorzy Kościoła. W jego zbiorze była także literatura humanistyczna: De viris illustris Boccaccia, Żywoty papieży Platiny, dzieła Eneasza Sylwiusza i Javiniana, dzieje Rzymu Illariusza, Kosmografia Ptolemeusza. Był to jeden z największych późnośredniowiecznych zbiorów prywatnych powstałych poza kręgiem Uniwersytetu Krakowskiego"153. W innym miejscu badacz ten ocenił tenże sam księgozbiór nieco inaczej: „Księgozbiór swój, liczący 125 wolumi-

${ }^{151}$ Ulanowski 1894, nr 912.

${ }^{152}$ Łukowski studiował w Krakowie, a następnie w Rzymie. Był notariuszem w konsystorzu poznańskim (1461-1464), wikariuszem generalnym poznańskim (1499-1503), notariuszem, a następnie kanclerzem biskupów Andrzeja Bnińskiego i Uriela z Górki, a wreszcie administratorem diecezji poznańskiej po śmierci biskupa Uriela, w okresie od 22 lutego 1498 r. do 24 stycznia 1499 r. Zob. Dembiński, Wykształcenie pratatów, s. 57-59.

${ }^{153}$ J. Wiesiołowski, Łukowski Jan, WSB, s. 441. 
nów, przekazał kapitule poznańskiej. Mimo znacznych rozmiarów księgozbioru i wysokich godności w kapitule, zestaw książek ujawnia brak wyższego, uniwersyteckiego wykształcenia zbieracza. Prawo kanoniczne reprezentują głównie popularne kompendia, komentarze prawnicze są sporadyczne, głównie - wielotomowe komentarze Panormitana i Sandeusza. Wśród dzieł teologicznych brak co prawda zbiorów kazań czy popularnych kompendiów, lecz przeważają dawni klasycy teologii. Wagę księgozbiorowi Łukowskiego nadają książki historyczne i humanistyczne: Vitae pontificum (Platiny?), kosmografia Ptolemeusza, kronika Euzebiusza, dzieła Eneasza Sylwiusza, historia rzymska Illaria, De viris illustribus Boccaccia; bez nich księgozbiór, mimo pokaźnych rozmiarów, utrzymywałby się w kanonie lektur czołówki altarystów, podobnie jak Łukowski uzupełniających wykształcenie drogą samokształcenia" 154 .

Z tą ostatnią opinią można, jak się zdaje, polemizować. Pewna część księgozbioru Łukowskiego posiadała charakter użytkowy, a nie samokształceniowy. Zbiory takie jak Decisiones rote [Romanae], De potestate Romani pontificis, Acta concilii Constantinensis, Formulare terminorum, Dictionarius iuris, Processus iuris, Compendium iuris, De auctoritate summi pontificis et cardinalium, Statuta Regni Polonie nie stanowiły popularnej literatury dla słabo wykształconego czytelnika. Mamy tu wyraźnie do czynienia z podręcznym księgozbiorem fachowym, wykorzystywanym przez prawnika w jego działaniach zawodowych, być może także w sporządzaniu - jak byśmy to dziś nazwali - pewnego rodzaju ekspertyz. $\mathrm{Z}$ drugiej strony znajdujemy $\mathrm{w}$ tym inwentarzu także najpopularniejsze średniowieczne „czytadło” - Ztota legendę.

Zwraca wreszcie uwagę fakt, że niektóre tytuły pojawiają się w tym inwentarzu kilkakrotnie: Decretum cztery razy (w tym także skróty i wypisy), Decretales trzy razy, Dictionarius iuris łącznie trzy razy, z czego jeden egzemplarz rękopiśmienny, dwa pozostałe zaś prawdopodobnie już drukowane. Mamy tu do czynienia raczej z dubletami niż z pomyłką pisarza. Są to teksty o szczególnym znaczeniu, wobec czego posiadanie kilku różnych egzemplarzy, być może z różnymi glosami, komentarzami, objaśnieniami, daje się racjonalnie wythumaczyć. Bardziej zagadkowe jest natomiast pojawienie się w spisie zarówno dzieła pod tytułem Cosmogravia, jak i, 15 pozycji niżej, imienia Ptolemeusza. Oczywiście nie możemy wykluczyć, że Łukowski posiadał dwa egzemplarze Kosmografii Ptolemeusza, albo też że autorem jednej z nich nie był starożytny grecki astronom ${ }^{155}$, w tym przypadku jednak możliwa jest również pomyłka pisarza. Interesująca jest wreszcie informacja, na którą nie zwrócił uwagi J. Wiesiołowski, o - zapewne cennym - pergaminowym rękopisie iluminowanym:

„Rdi patris dni Iohannis de Lucowo archidiaconi et tunc vicarii in Spiritualibus Gnezn., decani et canonici Poznan. ac Wladislav. ecclesiarum viri magnarum virtutum et grandeve etatis et dignitatis LXXX circiter annos habentis, qui anno dominice Nativitatis 1514 d. dominica festi Transfigurationis Dni [6 Augusti], dum nona in ecclesia decantabatur ecclesiasticis sacramentis procuratus in pace

\footnotetext{
${ }^{154}$ Wiesiołowski, Społeczeństwo a książka, s. 70-71.

${ }^{155}$ Cosmographia Sebastiana Münstera opublikowana została dopiero w 1544 r.
} 
quievit in capella dni Urielis epi Pozn. in sepulcro eiusdem et iuxta ipsum tumulatus, regestrum librorum ac dni Iohannis Crotoski ecclesie Poznan. legatorum:

Processus iuris scriptus

Textus Clementine cum Extra

Speculatoris secunda pars

Breviarium Decreti cum margarita Decreti

Abbas super primum et secundum

Abbas super III et II

Abbas super primum

Abbas super tertium

Felinus super II et IV

Felinus super I

Speculi secunda pars

Prima pars Panthologie

Allexander de Ales in quinque voluminibus

Albertus super „Missus est”

Decretum

Calderini repertorium

Decretales bine in parvo volumine

Casus summarii Bernardi

Lumbartica hystoria

Prima epistolarum Ieronimi

Isodorus

Liber de sanguine Christi

Rubertus super sapientie

Decretales

Decretum

Prima pars S. Theologie

Tertia pars S. Theologie

Catholicon

Breviloquus

Robertus de victoria verbi Dei

Secunda pars Panthologie

Speculum morale Vincencii

Moralia b. Gregorii

Lira super librum sapientie et prophetas

Glosa ordinaria super vetus testamentum

Tertium et quartum hystorie Vincentii

Primum et secundum Vincentii

Lira super novum testamentum

Lira super iudic. et pen.

Glosa ordinaria super librum sapientie et prophetas

Biblie textus

Secunda pars S. Theologie

Sermones de Turre Cremata 
Dionisius de celesti ierarchia

Prima pars summe predicantium

Secunda pars summe predicantium

Epistole Petri Blesensis

Hostiensis prima

Hostiensis secunda

Summa angelica

Decisiones rote

Vite pontificum

Iovinianus

Operum b. Augustini XI volumina

Cosmogravia

De potestate Romani pontificis

Liber scriptus in pargameno cum ymaginibus

Cronica Euzebii

Acta concilii Constantinensis

Speculum questionum peregrinarum

Opera Pii pape

Dictionarius iuris

Formulare terminorum

Anama super V

Decretum

Augustinus super Iohannem

Sextus

Decretum

Ieronimus super prophetas

Bernardus Cordubensis

Ptolomeus

Dominicus super Sextum

Hermolai liber

Statuta Regni Polonie

Processus iuris

Compendium iuris

Felinus super I

Decretales

Secunda pars repertorii Brikczensis

Textus epistolarum et Evangelii scriptus

Speculi IV partes

Textus sententiarum

Illarius ab Urbe condita

Tertia pars Felini

Prima repertorii Brikczensis

De auctoritate summi pontificis et cardinalium

Secunda pars epistolarum Ieronimi

Canones Augustini 
Rudimenta Ebraica

Quinquagena Augustini

Gregorius super Ezechielem

Opera Augustini minora

Bocacius de casibus illustrium

Bernardus super cantica

Albertus de officio misse

Textus Clementine

Epistole Augustini

Valensis de ordine minorum

Thomas super Evangelia

Repertorium Abbatis

Innocentius

Iohannes Andree

Prepositus super Decretum

Imola super Clementinis

Alexander super quartum

Repertorium iuris

Opera b. Ambrosii

Liber de diversis tractatibus

Vita Cristi

Epistole Ieronimi

Hugo de sacramentis. Summa CXXV (s) ${ }^{156}$.

Tenże Jan Łukowski osiem lat przed śmiercią, 28 lipca 1506 roku, zwrócił kapitule jakieś akta, nazwane księgami, z czasów biskupa Andrzeja z Bnina, którego był - przypomnijmy - kanclerzem. Księgi te członkowie kapituły nakazali złożyć w bibliotece: „Ibidem vener. dnus Iohannes de Lucowo decanus Poznan. Rmorum olim dnorum Andree de Bnyn et Urielis de Gorka eporum cancellarius reposuit acta seu libros memorati Andree epi quinque, quos dni ad librariam servare mandaverunt"157.

Trzecim wielkim legatem dla biblioteki kapitulnej był zapis testamentowy biskupa Jana Lubrańskiego. 8 marca 1521 roku wciągnięto do księgi metrycznej inwentarz ruchomości pozostałych po zmarłym biskupie, spisany przez notariusza kapituły Wojciecha (Alberta) Skrzetuskiego 23 maja 1520 r. Jednakże już następnego dnia, na podstawie umowy między nowym biskupem poznańskim Piotrem Tomickim a Mikołajem Lubrańskim, wojewodą poznańskim, bratem zmarłego biskupa Jana, wszystkie pozostałe po nim rzeczy, spisane szczegółowo w księdze metrycznej kapituły, zabrał Mikołaj ${ }^{158}$, książki pozostały jednak własnością Kościoła. Analizę tej niezwykle ciekawej, bogatej w dzieła autorów antycznych ko-

\footnotetext{
${ }_{156}$ Ulanowski 1894, nr 1054.

${ }^{157}$ Ulanowski 1894, nr 1010.

${ }^{158}$ Ulanowski 1894, nr 1110.
} 
lekcji zaprezentował przed dziesięciu laty Ryszard Marciniak ${ }^{159}$, wobec czego poniżej podaję jedynie sam inwentarz:

„Inventarium rerum post obitum olim Rmi dni Iohannis Lubranski Epi Pozn. derelictarum per me Albertum Scrzatuski notarium vener. capituli Pozn. de anno Dni 1520, XXIII Maii conscriptum ac de mandato et decreto Rmi dni Petri d. g. Epi Pozn. et sui... capituli huic metrice regestrarum et plenarie inscriptum (...) Libri post mortem prefati dni Epi Lubranski reperti:

Leonardus Aretinus

Liber privilegiorum de gestis Prussitarum

Salustius in pargameno scriptus

Guarinus in Plutarcum

Strabo

Orationes Ciceronis

Georgius Valla

Opera Anzelmi

Philostratus

Georgica

Plinius

Frontinus de aque ductu

Textus Decretalium

Albinus Tibulus

Pontificale

Confessio Valdensium cum epistolis ad regem Hungarorum

Iozephus de bello Iudaico

Strabo de situ orbis

Pedianus contra Pisonem

Libellus Publii ad dnum Iohannem Epum Crac.

Laurentinus Valdensis

Euzebius

Bulidanus

Plautus

Sextus Iulius Frontinus

Xenofon

Lucanus

Dialogus Gregorii

Historiarum Iustini

Persius cum commentis

Digestum novum

Petrus Crinitus de honestate discipline

Tragedie Senece

Epistole Philelphi Francisci

Commentaria Cezaris

${ }^{159}$ R. Marciniak, Biblioteka biskupa Jana Lubrańskiego, w: Jan Lubrański i jego dzieło, „Kronika Miasta Poznania”, 2 (1999) s. 111-126. 
Iuvenalis

Apianus de bellis civilibus

Clipeus contra Picardos

Erasmi Roterodani

Innocentius super Decretales

Sextus decretalium cum Clementinis

Sermones Crisostomi de patientia Iob

Dionisii Alicarnazii antiquitatum

Tragedie Senece

Felini 2da pars

Repertorium Bartochini 2da pars

Plutarcus de Viris illustribus

Speculator in II voluminibus

Iohannes de Imola super quarto

Summa Gofredi

Epistole b. Ieronimi

Iamblicus de misteriis Egiptorum

Epistole Ciceronis

Philipice Ciceronis

Petrus de Ancarano super Vito

Novella iohannis Andree super Vito

Cardinalis super Clementinas

Iohannis de Turrecremata de potestate pape

Raphael super 2da parte Digesti

Opera Ciceronis

Cronicorum liber

Ptholomei geographia

Plinius

Georgii Valle

Swetonius

Margarita poetica

Iohannes Garsonis de amicitia

Hystoria Hebreorum

Iozephus de captivitate Iudaica

Argiopili

Aulusiclius

Decades Blondini

Rethorica Casperini

Aldus de litteris Grecis

Fedon Aretini

Decreta concilii Basiliensis

Ianusii Oliveti de terre motu

Lucilus, Florus, Apulegius

Propersius

Iohannes Garsonis libellus 
Iulius Firmicus

Repertorium Gloscordi

Quintilianus

Iuvenalis

Suetonius

Valdensium confessio ad regem Hungarorum

Pauli Orosy

Epistole Senece

Lactantius

Marcus Tulius de finibus bonorum

Runmitus ad Nicolaum papam

Origenes in Genesim

Margarita Decreti

Epistole b. Cirilli in magno volumine

Opera Iohannis Crisostomi in III voluminibus

Diogenes

Repertorium Barthochini cum additionibus

Repertorium Corfeti in Abbatem

Repertorium Barthochini pars tertia

Albertus magnus de Alibuth

Codex

Felini pars prima

Imola super primum Decreti

Marcelly de proprietatibus sermonum

Autenticorum textus

Gregorii per trapetonsio prefatio

Quintus Culcius

Statuta regni

Barbatius de iudiciis

Baldus super primo Decretalium

Iohannes de Imola super Decretales

Barbatius de libellorum oblationibus

Idem de approbationibus

Idem de rebus ecclesie alienandis

Idem de verborum obligationibus

Prepositus de apellationibus

Defensiones in monachos

Item libri dno Oleski restituti

Iohanni Francisci Pici IV libri in uno volumine

Opera Dionisii

Opus b. Cirilli

Posterior pars Vapsodi

Venditi fuerunt:

Item Almanach

Epistole s. Ambrosii 
Libellus Petri Pauli Vangerii de motibus

Item opera Dionisii

Cornelii Taciti historie libri XI

Libellus Terentii Afri non integer

Item viaticus Crac

Iozephus antiquitatum

Item Sextus Iulius Frontinus

Tractatus s. Thome de Aquino in parvo modo

Ordo misse cum glossis sacri canonis

Opuscula divi Bernardi Clarevalensis abbatis

Opuscula s. Augustini

Titi Lucretii Caii de vir. natura

Pompey libri III de situ orbis in sexternis

Item II quinterni Xenofon

Laurentii Valle annotationes super vetus et novum testamentum

Item libri Oratii in sexternis

Pontani de amota libri II in sexternis

Phizonomia Glogovite non completa

Exercitum gramaticale puerorum per dicta distributum

Annotationes pandektharum incomplete

Liber memorie Erazmi in sexternis incompletus

Iliadum

Salustius in sexternis cum commento

Sexterni Suetonii incompleti

Missale Poznan. in papiro

Viaticum Pozn.

Biblia

Plinii epistola

Item libri per mgrum Valentinum depositi:

Iamblicus de misteriis Egiptiorum

Sermones Ephrem

Iulius Silinus de mirabilis mundi

Ciprianus

Petronius arbiter

Plinii Cecilii secundi epistolare

Temistius

Cornelius Celsus

Dionisius de situ orbis ${ }^{160}$.

Czwarty duży legat, przyjęty na posiedzeniu kapituły 8 listopada 1526 roku, pochodził z zapisu wikariusza generalnego i oficjała Mikołaja Oleskiego ${ }^{161}$. Na ironię zakrawa fakt, że nie jest on uwzględniany przez historyków zajmujących

\footnotetext{
${ }^{160}$ Ulanowski 1894, nr 1109.

${ }^{161}$ Nowacki, Zapiski historyczne, s. 172.
} 
się biblioteką kapituły - najprawdopodobniej dlatego, że został opublikowany przez Bolesława Ulanowskiego w innym miejscu niż trzy poprzednie ${ }^{162}$ :

„Libri post mortem Rdi patris dni Nicolai Oleski canonici vicariique in Spiritualibus et officialis generalis Poznan. viri profecto optimis moribus prediti, de ecclesia et personis eiusdem bene meriti, etatis sui LXXXIIII, octava Novembris appoplexia percussi in bonis viribus vita functi ad librariam ecclesie recepti sequuntur:

Inprimis viaticus dioceses Cracoviensis

Item opera tractatuum s. Anzelmi

Item translatio historiarum in Alamanicum

Item sermones Contracti de tempore

Item prefatio b. Gregorii in Iob

Item Augustinus de civitate Dei

Item Rabanus ad Ludovicum regem

Item liber Iohannis Francisci Pici

Item sermones Leonardi de Utino

Item liber scriptus de vita et honestate clericorum

Item liber epistolarum $b$. Augustini

Item liber decretalium in pergameno scriptus

Item supplementum Cronicarum

Item opera Dionisii duplicia in duobus voluminibus

Item sexta pars Antonini

Item Iamblicus de misteriis Egiptianorum

Item apologia in maleum maleficarum

Item [liber] epistolarum b. Ieronimi

Item liber historiarum Romanarum scriptus

Item sextus decretalium

Item tractatus Bonaventure

Item sermones Iohannis Crisostomi

Item tercia pars Antonini

Item Infortiatum de tortis

Item primus liber Ambrosii

Item Bartholomeus de proprietatibus rerum".

Była to biblioteczka o charakterze głównie teologicznym. Jedynie kilka pozycji z tego inwentarza zwraca szczególniejszą uwagę: niemiecki przekład być może żywotów świętych, dzieło o misteriach egipskich Jamblicha oraz popularna encyklopedia średniowieczna Bartholomeusa $O$ właściwościach rzeczy. Być może liber Iohannis Francisci Pici to De hominis dignitate Giovanniego Pico della Mirandoli. Ponadto znajdujemy tu trzy dzieła prawnicze oraz dwa historyczne.

Znamy wreszcie przypadek, gdy kanonik udający się na zagraniczne studia Jan Górski - oddawał na czas wyjazdu swoje księgi w depozyt bibliotece katedralnej. Odebrać je miał po szczęśliwym powrocie, natomiast gdyby w czasie

${ }^{162}$ Akta kapitut z wieku XVI wybrane. Tom I. Część I. Akta kapitut poznańskiej i włocławskiej (1519-1578), wyd. B. Ulanowski, Kraków 1908, s. 10. 
podróży zaskoczyła go śmierć, depozyt miał przejść na własność kapituły. Część tych ksiąg została od razu wypożyczona przez innych kanoników:

„A. 1501, Septembris 24, in capitulo

Ibidem vener. dnus Iohannes Gorsky canonicus Poznan. disponens se ad studium versus Italiam remansit et reposuit libros infrascriptos coram dnis videlicet: duo volumina partium Thome, item consilia Oleardi, item summam Baptiste de Saris ordinis Minorum, item sermones Roberti, item Plitarcum (s) de Viris illustribus, item Richardum de contemplacione, item sermones Roberti ad parvum modum impressos, quos dnus Dambrowa recepit in mutuum, item Decretales cum apparatu olim dni Scudla ad magnum modum, quos habuit idem dnus Gorski de libraria, recepit in mutuum dnus Czyesyelsky; item predicta duo volumina partium Thome recepit in mutuum dnus Grodzyczsky doctor; quos libros duntaxat idem dnus Iohannes Gorsky, si eum mori contigerit in illis partibus, legavit ecclesie, postquam tamen sanus redibit, eos rehabebit. Item dni decreverunt statutum de studentibus editum fore solvendum a proximo festo s. Martini per annum eidem dno Gorsky, in quantum de diligencia sua circa studium habenda docuerit per litteras Universitatis"163.

Na zakończenie wreszcie wspomnijmy o dwóch pomniejszych zapisach. Jakub Boksica, kanonik gnieźnieński, poznański i krakowski, profesor teologii i medycyny w Akademii Krakowskiej, doktor teologii, obojga praw i filozofii, zmarły w 1498 roku, „testamentem przekazał kapitule gnieźnieńskiej 37 woluminów dzieł, w większości prawniczych. Wykonawca jego ostatniej woli, kanonik gnieźnieński Klemens z Piotrkowa, złożył owe księgi do biblioteki kapitulnej. Również i kapitule poznańskiej zapisał trzy dzieła św. Grzegorza":

„Moralia sancti Gregorii

Dialogum eiusdem et super Ezechielem"164.

Także Tomasz Strzempiński, kanonik poznański, a później biskup krakowski $(† 1460)$ przekazać miał testamentem jakieś książki katedrze poznańskiej ${ }^{165}$, jednakże dokładnego ich wykazu nie znamy (powyżej omówiłem już jego zapis dla biblioteki gnieźnieńskiej).

Kapituła dbała nie tylko o swoją bibliotekę, ale także o produkcję książki drukowanej na terenie diecezji. 13 sierpnia 1520 roku oddano pusty plac w pobliżu kościoła, na którym niegdyś była cegielnia, introligatorowi Janowi Stryjowi, mieszczaninowi z Waliszewa ${ }^{166}$. Bez wątpienia transakcja ta miała związek z jego działalnością zawodową, ponieważ kapituła korzystała z usług Jana jako nakładcy. 1 września 1533 roku dokonano wyceny poprawionej agendy diecezjalnej oraz pa-

${ }^{163}$ Ulanowski 1894, nr 930.

${ }^{164}$ Korytkowski I, s. 59.

${ }^{165}$ Korytkowski IV, s. 36.

${ }^{166}$ „Vener dni et canonici... aream desertam post ecclesiam s. Nicolai, ubi laterificium erat constructum, consistentem in quantitate per dnos ad id deputatos emensuratam provido Iohanni Patruo librorum introligatori oppidano de Valiszewo donaverunt et dederunt in perpetuum in hereditatem, sub ea tamen conditione, ut edificium in eadem construende faciat et censum pro mensa dnorum hereditarium per XIV gr. annuatim solvat, cui tamen libertatem ab eiusdem et omnium aliorum onerum solutione hinc ad tres annos concesserunt et dederunt". Ulanowski 1894, nr 1098. 
sji ewangelicznych, wydanych w Lipsku nakładem waliszewskiego introligatora: „Dni... taxaverunt iusta moderacione previa agendas diocesis Poznan. sumptibus et impensis circumspecti [et] providi dni Iohannis civis Valischeviensis in Lypsko excussas in quaterniolis unacum IV passionibus Ewangelistarum quatuor notatis ad XVI gr. Absque introligacione, alias in forma meliori iuxta commisionem Rmi dni Epi Pozn."167

Oczywiście już wcześniej kapituła troszczyła się o druk ksiąg liturgicznych. $\mathrm{Z}$ datą 1 kwietnia 1505 roku, nakładem księgarza poznańskiego Piotra, wydany został mszał diecezji poznańskiej. Jak pisał J. Nowacki „zapewne powyższego wydania mszału nabyła w dniu 20 marca 1508 kapituła katedralna 30 egzemplarzy od kupca poznańskiego i wydawcy Piotra Bukwira, na poczet których otrzymał on był pożyczkę 30 grzywien" "168. Bukwirem nazywa ksiądz Nowacki kupca, ławnika miejskiego, księgarza i nakładcę Piotra z Lubeki, zmarłego w 1513 roku. Działał on w Poznaniu po roku $1470^{169}$.

W 1531 roku kapituła zatroszczyła się także o uruchomienie na terenie diecezji młyna papierniczego, w który miał zostać przekształcony dawny młyn zbożo$w^{170}$. Wzmianki na temat troski kapituły o księgarzy i papierników godne są szczególnej uwagi, ponieważ jest to jedyny taki znany mi przypadek w późnośredniowiecznej Polsce. Być może obserwujemy tu wpływy biskupa Jana Lubrańskiego.

Oprócz biblioteki kapituły katedralnej Poznań dysponował także innymi księgozbiorami kościelnymi. „Sądząc ze wzmianek istniała osobna biblioteka wikariuszy wieczystych oraz penitencjarzy katedralnych. Tworzyły się one głównie z darów. Podobna była geneza biblioteki kolegiaty św. Mikołaja, istniejącej już na przełomie XV i XVI w., prawdopodobne jest istnienie analogicznej biblioteki w kolegiacie NMP. Nie istniała natomiast biblioteka altarystów katedralnych, gdyż te prebendy w większości znajdowały się w posiadaniu kanoników katedry i wikariuszy wieczystych. Jakieś książki liturgiczne i muzyczne - w tym partytury organowe-musiały się znajdować u mansjonarzy działających w katedrze a także u psałterzystów fundowanych przez biskupa Lubrańskiego. [...] W poznańskiej kolegiacie św. Marii Magdaleny pierwszy księgozbiór uformował się w pocz. XV w. jako zależna od proboszcza bibliotheca predicatorum gromadząca książki użyteczne w kaznodziejstwie, już przed 1447 r. uzyskując osobne pomieszczenie w kaplicy nad zakrystią. Gwałtowny przyrost altarystów (w 1510 r. Liber beneficiorum

${ }^{167}$ Ulanowski 1908 , s. 25.

${ }^{168}$ Nowacki, Kościót katedralny w Poznaniu, s. 769.

${ }^{169}$ Por. biogram A. Głowacka, Piotr z Lubeki, WSB, s. 570.

170 „Dni... prebuerunt consensum provido Thome de Vratislavia efendi molendinum in villa Zarady Nadolny nuncupatum, cui eciam pro meliori mense eorum capitularis condicione facienda aream iuxta hocidem molendinum consistendem absque omni domno dicti molendini ac sine imminutione pratorum et agrorum ad mensam capitularem pertinentium pro construendo officina molendini papirei [concesserunt], de quaquidem officina per ipsum Thomam construenda tenebitur et debebit solvere annuatim pro mensa capitulari, expirata libertate trium annorum, a prox. futuro festo s. Martini incipiendo III marcas pecunie receptibilis, et nichilominus de ipso molendino farine nunc existendi exnunc absque omni libertate tenebitur solvere... etc.”, Ulanowski 1908, s. 18-19. 
wylicza 59 altarii) spowodował, że grupa ta utworzyła przed 1491 rokiem własną bibliotekę. Niezależnie od tego niektóre altarie posiadały własne małe księgozbiory. Późne powstanie kolegiaty i dość specyficzne funkcje członków jej kapituły spowodowały, iż do pocz. XVI w. nie powstała tam osobna biblioteka kapitułykolegiackiej.Ilośćksiągliturgicznychmusiałabyćimponującawzwiązkuzogromną ilością prebend w kościele, ufundowanych głównie przez czołowe rodziny patrycjuszowskie miasta, najbogatsze cechy oraz bractwo Wniebowzięcia NMP, czołowe i zamożne bractwo religijne miasta. Mimo zamożności i ogromu fundacji kolegiata św. Marii Magdaleny zapewne ustępowała jako centrum kultury książkowej niektórym innym kolegiatom wielkopolskim, które jak Kalisz, Łęczyca, Sieradz czy Łowicz były jednocześnie nieposiadającymi konkurencji katedralnej centrami życia kulturalnego i religijnego regionów.

Mimo sporej ilości informacji, trudno wskazać wybitnych bibliofili poznańskich z okresu książki rękopiśmiennej. Silniejsze indywidualności można znaleźć na przełomie XV i XVI w., gdy przeważała książka inkunabułowa. Ofiarodawcy książek, głównie członkowie kapituły, posiadali przeważnie książki używane w kręgu uniwersyteckim. Czasem wiadomo o bibliotece - jak u biskupów Andrzeja Łaskarzewica czy Stanisława Ciołka - ale brak wykazów książek i zachowanych woluminów. Rękopisy iluminowane natomiast należały częściej do osób nieznanych z szerszych zainteresowań intelektualnych [lub też instytucji, np. kościoła katedralnego czy kolegiackiego - PT]"171.

\section{Podsumowanie}

Zarówno w Gnieźnie, jak i w Poznaniu zapisy dotyczące książek prowadzono niejednolicie, bez stosowania jakiegokolwiek schematu. Nie istniał oczywiście wówczas żaden odpowiednik dzisiejszego formatu opisu bibliograficznego, a ponadto inwentarze spisywano z natury, tak jak książki leżały w skrzyni bądź stały na półkach, wobec czego nie przestrzegano także żadnej logicznej kolejności. Nawet dzieła wielotomowe były rozbijane na poszczególne tomy, które wymienia się w różnych miejscach inwentarza. Co więcej, podczas kontroli wypożyczeń 30 października $1455 \mathrm{r}$. tę samą osobę wymienionono dwukrotnie pod różnymi imionami, raz jako Jana z Brzostkowa, a dalej jako Jana Neposa.

Można zastanawiać się, czy uprawnione jest porównywanie księgozbiorów kapitulnych późnego średniowiecza ośrodków poznańskiego i gnieźnieńskiego. Otóż wydaje się, że w formułowaniu takich porównań należy być bardzo ostrożnym, ponieważ rozpatrujemy tu kolekcje tworzone nieplanowo i systematycznie przez świadomą swych celów i potrzeb instytucję, lecz rozrastające się dość przypadkowo głównie dzięki legatom testamentowym. Dynamika narastania zbioru, taka, jaką możemy zaobserwować na podstawie omawianych źródeł, zależała od indywidualnych zainteresowań poszczególnych kanoników, prałatów oraz biskupów, nie zaś od instytucjonalnych decyzji gremium. W głównym zrębie legaty w obu ośrodkach wielkopolskich (pomijając zapis Jana Lubrańskiego) były dość podobne i mamy tu do czynienia przede wszystkim z użytkowymi zbiorami teolo-

${ }^{171}$ Wiesiołowski, Średniowieczne biblioteki, s. 13-14. 
giczno-prawniczymi. Dzięki legatom duchowieństwa kapitulnego, przekazującego na rzecz kongregacji swoje księgozbiory podręczne, powstały zręby bibliotek fachowych, gromadzących zasób wykorzystywany przez kanoników i prałatów w ich działalności, jak byśmy dziś powiedzieli, zawodowej. Natomiast polityka świadomego kształtowania tychże bibliotek narodziła się dopiero u schyłku wieku XV. Niemniej już wcześniej obie kapituły dbały o posiadane książki, regulując sprawy wypożyczeń, nakazując wpłacanie kaucji i dokonując przeglądów wypożyczonych książek, a także rewindykując księgi pozostające w spuściźnie zmarłych prałatów czy biskupów.

słowa kluczowe: biblioteka, starodruki, kapituła katedralna, Gniezno, Poznań, Bolesław Ulanowski,

\author{
THE LIBRARIES OF THE CATHEDRAL CHAPTERS IN GNIEZNO \\ AND POZNAŃ IN THE FIFTEENTH AND EARLY SIXTEENTH CENTURY
}

\begin{abstract}
Summary
The article presents the role of books in two important chapter centres of the former Poland, Gniezno and Poznań, in the period between the 1430s and the 1530s. It is based on the source extracts from the chapter records made by Boleslaw Ulanowski. The aim of this paper is, apart from the presentation of author's findings, a summary and systematization of the information about libraries of the chapters, which to some extent has already been introduced into science.

The article is divided into two parts. The first focuses on the library of Gniezno, the other Poznan. Each of the two parts begins with the issues of the premises in which the collections were deposited. Next, the author continues to discuss in detail the issues of increasing the book collection (gifts and testamentary legacies), its content, maintenance, and borrowing as well as carers and users, both from inside the chapter, as well as outside it. The source quotations, given in extenso, play an important role; they have not been mentioned in the literature since B. Ulanowski's publication.

The introductory part of the paper discusses the previous literature on the issues of the Polish cathedral chapter libraries.
\end{abstract}

Keywords: library, manuscripts, cathedral chapter, Gniezno, Poznań, Bolesław Ulanowski, 